\title{
1 Severe COVID-19 induces molecular signatures of aging in the human
}

\section{2 brain}

3

4 Maria Mavrikaki ${ }^{1,4 \#}$, Jonathan D. Lee ${ }^{1,4}$, Isaac H. Solomon² and Frank J. Slack ${ }^{1,3 \#}$

5

$6{ }^{1}$ Department of Pathology, Beth Israel Deaconess Medical Center, Harvard Medical School,

7 Boston, MA 02215, USA

8 'Department of Pathology, Brigham and Women's Hospital, Harvard Medical School, Boston, MA, $9 \quad 02215$, USA

$10{ }^{3}$ Harvard Medical School Initiative for RNA Medicine, Harvard Medical School, Boston, MA 02215,

11 USA

$12 \quad{ }^{4}$ These authors contributed equally: Maria Mavrikaki and Jonathan D. Lee

14 "Correspondence to M.M. and F.J.S.: mmavrika@bidmc.harvard.edu; fslack@bidmc.harvard.edu 
medRxiv preprint doi: https://doi.org/10.1101/2021.11.24.21266779; this version posted November 24, 2021. The copyright holder for this preprint (which was not certified by peer review) is the author/funder, who has granted medRxiv a license to display the preprint in perpetuity.

It is made available under a CC-BY-NC-ND 4.0 International license .

\section{Abstract}

Coronavirus disease 2019 (COVID-19) is predominantly an acute respiratory disease caused by severe acute respiratory syndrome coronavirus 2 (SARS-CoV-2) and remains a significant threat to public health. COVID-19 is accompanied by neurological symptoms and cognitive decline, but the molecular mechanisms underlying this effect remain unclear. As aging induces distinct molecular signatures in the brain associated with cognitive decline in healthy populations, we hypothesized that COVID-19 may induce molecular signatures of aging. Here, we performed whole transcriptomic analysis of human frontal cortex, a critical area for cognitive function, in 12 COVID-19 cases and age- and sex-matched uninfected controls. COVID-19 induces profound changes in gene expression, despite the absence of detectable virus in brain tissue. Pathway analysis shows downregulation of genes involved in synaptic function and cognition and upregulation of genes involved in immune processes. Comparison with five independent transcriptomic datasets of aging human frontal cortex reveals striking similarities between aged individuals and severe COVID-19 patients. Critically, individuals below 65 years of age exhibit profound transcriptomic changes not observed among older individuals in our patient cohort. Our data indicate that severe COVID-19 induces molecular signatures of aging in the human brain and emphasize the value of neurological follow-up in recovered individuals.

\section{Introduction}

Although COVID-19 is primarily a respiratory disease, neurological symptoms are also reported in a subpopulation of infected COVID-19 individuals [1], with substantially higher rates (up to $84 \%$ ) in severe COVID-19 cases [2]. For instance, patients with prior severe COVID-19 exhibit a 10-year average drop in their global cognitive performance [3]. Complementary studies combining neuroimaging and cognitive screening implicate COVID-19-induced impairment of the frontal cortex [4, 5], a critical area for cognitive function [6, 7]. Furthermore, the effects of COVID19 on the nervous system, including cognitive impairment, are expected to be long-term [3, 8-10]. 
medRxiv preprint doi: https://doi.org/10.1101/2021.11.24.21266779; this version posted November 24, 2021. The copyright holder for this preprint (which was not certified by peer review) is the author/funder, who has granted medRxiv a license to display the preprint in perpetuity.

It is made available under a CC-BY-NC-ND 4.0 International license .

41 However, the molecular mechanisms underpinning the effects of COVID-19 on cognition remain

42 to be determined.

In healthy populations, the natural process of aging leads to a reduction in frontal cortex

44 activity [11] and cognitive decline [12]. At the molecular level, aging induces distinct molecular

45 signatures in the human brain, including increased activation of immune signaling and decreased

46 synaptic activity [13-15]. Based on the deteriorating effects of COVID-19 on the frontal cortex and

47 on cognitive function, paralleling the effects of aging, we hypothesized that COVID-19 induces

48 molecular signatures of aging in the frontal cortex.

COVID-19 gene expression in human brain

To test this hypothesis, we performed whole transcriptomic analyses of postmortem frontal

51 cortex of 12 severe COVID-19 patients (with pre- or peri-mortem positive testing for SARS-CoV-

522 by nasopharyngeal swab qPCR and history of hospitalization) and 12 age- ( \pm 2 years) and sex-

53 matched uninfected controls (Fig. 1a). Clustering analysis via t-distributed stochastic neighbor

54 embedding (TSNE) reveals separation of COVID-19-associated transcriptomic profiles from

55 control profiles (Fig. 1b), with the two controls proximal to COVID-19 cases being from elderly

56 patients (ages 71 and 84). To assess whether this clustering is due to the presence of SARS-

57 CoV-2 virus, we tested frontal cortex samples by quantitative PCR (qPCR) using two different

58 primer sets recommended by the Center for Disease Control and Prevention (Fig. 1c,

59 Supplementary Fig. 1a). No signal was detected above background noise for either of these

60 primer sets. Bioinformatic alignment of sequencing reads to the SARS-CoV-2 genome also did

61 not detect viral reads in COVID-19 or control samples (Supplementary Fig. 1b). In agreement

62 with previous studies [16, 17], our data show absence of detectable virus in the frontal cortex at

63 the time of death and suggest that the observed gene expression changes are not due to direct

64 effects of SARS-CoV-2 virus in the frontal cortex. 
medRxiv preprint doi: https://doi.org/10.1101/2021.11.24.21266779; this version posted November 24, 2021. The copyright holder for this preprint (which was not certified by peer review) is the author/funder, who has granted medRxiv a license to display the preprint in perpetuity.

It is made available under a CC-BY-NC-ND 4.0 International license .

We next compared COVID-19 cases to their corresponding age- and sex-matched controls and identified a total of 2,809 differentially expressed genes (DEGs) with unique Ensembl gene IDs, 1,397 of which were upregulated and 1,412 downregulated (Fig. 1d, Supplementary Fig. 2a-b). In the human brain, we did not observe expression of genes involved in SARS-CoV-2 entry, such as ACE2 or TMPRSS2 (Supplementary Fig. 2c) [8, 16]. On the other hand, S100A8/S100A9 genes, which encode for calprotectin and circulating levels of which distinguish severe from mild COVID-19, were upregulated among COVID-19 patients in our cohort [18, 19]. In addition, SYNGR1, previously found to be downregulated in astrocytes and monocytes/macrophages in the prefrontal cortex of severe COVID-19 patients [17], was also downregulated in our cohort. Taken together, our analysis recapitulates many gene expression findings previously associated with COVID-19.

To determine the functional roles of COVID-19 transcriptome-wide changes, we performed pathway enrichment analysis using annotated Gene Ontology (GO) Biological Processes (Fig. 1e). To our surprise, we found numerous significant DEGs and GO terms associated with aging in the human brain to be significantly enriched upon severe COVID-19. In agreement with previous studies [16, 17], we observed positive enrichment of immune response terms (GO:0002376; GO:0002253) together with many immune-related genes upregulated in our cohort (e.g., BCL2, IFI16, and CFH) (Fig. 1e and Supplementary Fig. 3). Of the top dysregulated genes, we observed significant increases in IFITM1-3 gene expression levels, which are associated with interferon response [20]. Furthermore, we identified numerous synaptic function terms to be negatively enriched, including synaptic signaling (GO:0099536), regulation of synaptic plasticity (GO:0048167), and glutamatergic (GO:0035249), GABAergic (GO:0051932), and dopaminergic (GO:0001963) synaptic transmission, with corresponding downregulation of synaptic signaling genes (SST, GRIA1, and GRIN2B) (Fig. 1e and Supplementary Fig. 3). Indeed, SST, one of the most downregulated genes in our COVID-19 cohort, has been previously 
medRxiv preprint doi: https://doi.org/10.1101/2021.11.24.21266779; this version posted November 24, 2021. The copyright holder for this preprint (which was not certified by peer review) is the author/funder, who has granted medRxiv a license to display the preprint in perpetuity.

It is made available under a CC-BY-NC-ND 4.0 International license .

associated with aging in the human frontal cortex [14, 21]. We also observed significant associations of cellular response to DNA damage (GO:0006974) [14, 22], mitochondrial function (GO:0007005), regulation of response to stress (GO:0080134) and oxidative stress (GO:0006979), vesicular transport (GO:0016192), calcium homeostasis (GO:0055074) [14], apoptosis (GO:0042981) [23], and insulin signaling (insulin secretion: GO:0030073) [24-26] pathways previously associated with aging processes and brain aging [14, 21]. Critically, numerous COVID-19 DEGs are involved in cognitive function (cognition: GO:0050890; memory: GO:0007613, GO:0007616; and learning or memory: GO:0007611). Assessment of the DEGs overlapping with these enriched pathways reveals genes such as the brain-derived neurotrophic factor (BDNF) which have been associated with aging [27, 28](Fig. 1f). KEGG and Reactome pathway enrichment analyses also reveal positive enrichment of immune activation and negative enrichment of synaptic function pathways (Supplementary Fig. 4). Interestingly, KEGG analysis identifies the "Coronavirus Disease - COVID-19" pathway, based largely on non-brain tissue effects of COVID-19, as one of the most significantly enriched pathways among COVID-19 patients (Supplementary Fig. 4). Altogether, our analyses suggest that many biological pathways that change with natural aging in the brain also change in severe COVID-19.

\section{Molecular signatures of brain aging}

Based on the significant enrichment patterns of cognition pathways in COVID-19 brains, together with the numerous enriched biological processes associated with aging, we sought to test whether severe COVID-19 induces similarly widespread transcriptomic changes as aging in the human frontal cortex. We collated transcriptome-wide datasets from five independent patient cohorts assessing age-dependent changes in the frontal cortex (Fig. 2a). For all frontal cortex aging datasets, genes upregulated in aging are upregulated in severe COVID-19; likewise, genes downregulated in aging are also downregulated in severe COVID-19 (Fig. 2b-c and Supplementary Fig. 5). Furthermore, a gene set previously associated with brain aging is 
medRxiv preprint doi: https://doi.org/10.1101/2021.11.24.21266779; this version posted November 24, 2021. The copyright holder for this preprint (which was not certified by peer review) is the author/funder, who has granted medRxiv a license to display the preprint in perpetuity.

It is made available under a CC-BY-NC-ND 4.0 International license .

115

116

117

118

119

120

121

122

123

124

125

126

127

128

129

130

131

132

133 strongly upregulated in COVID-19 patients [29] (Supplementary Fig. 6). As additional support of this association between frontal cortex aging and severe COVID-19, we confirmed upregulation of S100A9, MYL12A, and RHOBTB3 genes and downregulation of CALM3, INPP4A, GRIA1, and GRIN3A in COVID-19 patients by qPCR, genes that are also differentially expressed in aged frontal cortex (Fig. 2d). Thus, a substantial set of DEGs in aged frontal cortex are also differentially expressed in the frontal cortex of severe COVID-19 patients.

Next, we sought to determine if the aging gene signature in the brain might differ between younger (at or below 65 years of age, $n=7 /$ group) and older (above 65 years of age, $n=5 /$ group) patients in our study cohort. To our surprise, we observed substantial transcriptomic changes upon COVID-19 infection in the younger patient cohort, with minimal observable gene expression changes in the older cohort (Fig. 2e-f). In older patients, COVID-19 upregulated the expression of only 19 genes, including $H B B, H B A 1$ and $H B A 2$, and downregulated the expression of 4 genes (Fig. 2f). Among younger individuals (at or below 65 years of age), we identified 1,631 upregulated genes and 2,073 downregulated genes in COVID-19, with many of the same DEGs from the age-/sex-matched full cohort also exhibiting significant differential expression. Furthermore, these DEGs retain the same significant trends with aging-associated genes in the frontal cortex (Fig. 2g-h and Supplementary Fig. 7). Altogether, our analyses suggest that the brain aging effects of COVID-19 are far more pronounced in younger patients than in older patients.

Finally, we tested whether the molecular changes in the brain induced by COVID-19 differ between males ( $n=7 /$ group) and females ( $n=5 /$ group). We observed many significant DEGs in both male (811 DEGs with unique Ensembl gene IDs; 396 were upregulated and 415 were downregulated) and female (408 DEGs; 231 were upregulated and 177 were downregulated) cohort subsets, including DEGs from our full cohort analysis (Supplementary Fig. 8a-c). Furthermore, both males and females exhibit concordant changes in aging-associated genes and 
medRxiv preprint doi: https://doi.org/10.1101/2021.11.24.21266779; this version posted November 24, 2021. The copyright holder for this preprint (which was not certified by peer review) is the author/funder, who has granted medRxiv a license to display the preprint in perpetuity.

It is made available under a CC-BY-NC-ND 4.0 International license .

140

141

142

143

144

145

146

147

148

149

150

151

152

153

154

155

156

157

158

159

160

161

162

163

pathways upon COVID-19 (Supplementary Fig. 8d-e). Thus, both males and females exhibit aging-associated transcriptomic changes in the frontal cortex due to severe COVID-19.

\section{Discussion}

Several studies have been published assessing the transcriptomic changes induced by severe COVID-19 in the human brain [16, 17, 30]. In agreement with our findings, single cell RNAseq studies of COVID-19 frontal cortex have identified increased immune activities $[16,17]$ and decreased expression of genes involved in synaptic signaling [16], together with the absence of detectable SARS-CoV-2 expression at the time of death $[16,17]$. However, no study has yet demonstrated the striking and profound similarities of transcriptomic profiles between COVID-19 disease and aging in the human brain. We believe this is for two reasons: (1) our patient cohort was rigorously age- and sex-matched, and (2) the effects of COVID-19 on the brain are most substantial among patients younger than 65 years of age, multiple of who are represented in our cohort. Indeed, a recent RNA-seq study of the frontal cortex of COVID-19 individuals all above 67 years of age identified minimal transcriptomic changes (11 differentially expressed genes) [30]. Of the differentially expressed genes reported, we also observed $H B A 1, H B A 2$, and $H B B$ genes upregulated in our older patient cohort subset (>65 years of age). Further mechanistic assessment of the brain aging-like profile observed among COVID-19 patients should thus be focused on younger patient cohorts to capture these substantial transcriptomic effects.

We recognize limitations in our study design: the variability in illness duration, the imperfect quality of several samples (as previously reported in similar studies [16]), the modest number of subjects (12 cases and 12 controls), the lack of young COVID-19 subjects, and the specificity of our findings due to COVID-19. Despite these constraints, we were sufficiently powered to identify substantial transcriptome-wide changes between COVID-19 cases and 
medRxiv preprint doi: https://doi.org/10.1101/2021.11.24.21266779; this version posted November 24, 2021. The copyright holder for this preprint (which was not certified by peer review) is the author/funder, who has granted medRxiv a license to display the preprint in perpetuity.

It is made available under a CC-BY-NC-ND 4.0 International license .

164

165

166

167

168

169

170

171

172

173

174

175

176

177

178

179

180

181

182

183

184

185

186

controls, including among younger patients in our patient cohort. Furthermore, in addition to being age-matched, our experimental sample size is larger than previously reported COVID-19 brain transcriptome studies [16, 17, 30], enabling the identification of aging-associated gene expression signatures in our samples. Although our study does not examine the specificity of COVID-19induced transcriptomic changes in the brain, the implications of our findings may readily extend to related pathologies. For instance, prior clinical trials have shown that cognitive impairment is observed in $55 \%$ of survivors of severe acute respiratory syndrome (SARS) 12 months after discharge [31]. Such behavioral observations suggest that similar molecular effects in the brain may be observed not only in severe COVID-19 but also in other conditions characterized by increased peripheral and central inflammation, severe hypoxic insults, and microvascular brain pathologies [1, 32].

Aging is a major risk factor for the development of cognitive deficits and neurodegenerative diseases [12, 33, 34]. Although the molecular changes in the brain upon COVID-19 cannot be readily assessed in recovered individuals, our data herein suggest that severe COVID-19 induces premature aging in the human brain, particularly among younger individuals. Together with previously reported residual cognitive deficits observed in recovered COVID-19 individuals [3], our results imply that increased long-term rates of cognitive decline and neurodegenerative disorders may be observed among COVID-19 patients as a consequence of long COVID. In light of this possibility, we advocate for neurological follow-up of recovered COVID-19 patients and suggest potential clinical value in modifying risk factors to reduce the risk or delay the development of aging-related neurological pathologies such as dementia [35]. 
medRxiv preprint doi: https://doi.org/10.1101/2021.11.24.21266779; this version posted November 24, 2021. The copyright holder for this preprint (which was not certified by peer review) is the author/funder, who has granted medRxiv a license to display the preprint in perpetuity.

It is made available under a CC-BY-NC-ND 4.0 International license .

\section{Acknowledgments}

189 This work was supported by a grant from the NIA (R01 AG058816) to F.J.S. We thank the National 190 Institutes of Health (NIH) NeuroBioBank, the Harvard Brain Tissue Resource Center (HBTRC), 191 and the Miami Brain Endowment Bank for providing control brain tissues. We also thank Dr. 192 Sabina Berretta, Director of the HBTRC, for advice on the selection of appropriate brain area 193 controls and Tanvi Saxena for advice on library preparation. We thank the BIDMC IBC and Robert

194 Griffin for advice on BL2+ protocols, Dr. Victoria Petkova for RNA-seq library quality control, and 195 Dr. loannis Vlachos for sequencing assistance.

197 Author Contributions

198 M.M. conceived of the idea and designed the study. M.M. performed the library preparation for 199 RNA-seq and qPCR experiments. J.D.L. performed bioinformatic analyses and generated all 200 relevant files including codes. I.H.S. generated the relevant IRB protocol, collected COVID-19 201 patient brain tissues, provided clinical annotations and determined the appropriate brain area for 202 the controls. F.J.S. and M.M. supervised the study. M.M., J.D.L. and F.J.S. wrote the manuscript. 203 All authors reviewed and edited the manuscript prior to submission.

204 Declarations of interests

205 The authors declare no conflicts of interest. 
medRxiv preprint doi: https://doi.org/10.1101/2021.11.24.21266779; this version posted November 24, 2021. The copyright holder for this preprint (which was not certified by peer review) is the author/funder, who has granted medRxiv a license to display the preprint in perpetuity.

It is made available under a CC-BY-NC-ND 4.0 International license .

207

208

209

210

211

212

213

214

215

216

217

218

219

220

221

222

223

224

225

226

227

228

229

230

\section{Methods}

\section{Human brain tissues}

Post-mortem brain tissue specimens from individuals with severe COVID-19 were collected through an excess tissue waived consent protocol approved by the Mass General Brigham Institutional Review Board. Consent for autopsy was provided by the patients' next of kin or healthcare proxy per Massachusetts state law. All autopsies were performed at Brigham and Women's Hospital from 9/1/2020 to 3/30/2021 with pre- or peri-mortem positive testing for SARSCoV-2 by nasopharyngeal swab qPCR. COVID-19 cases had no known psychiatric or neurological disorder (two cases had history of prior stroke). Tissues collected within a postmortem interval (PMI) less than 48 hours were included. At the time of autopsy, brains were sectioned coronally, and samples of middle frontal gyrus (alternating between left and right sides in the absence of gross abnormalities) were collected and frozen at $-80^{\circ} \mathrm{C}$. Frozen middle/superior frontal gyrus (Brodmann area 8) controls were obtained from the NIH NeuroBioBank (Harvard Brain Tissue Resource Center/HBTRC and the University of Miami's Brain Endowment Bank). Controls were selected to be age- and sex-matched to a COVID-19 case and were categorized as unaffected controls (with no known psychiatric or neurological condition) in the $\mathrm{NIH}$ NeuroBioBank system. All controls were collected prior to the COVID-19 outbreak in the United States (before 11/2019) and thus are considered uninfected by SARS-CoV-2. RNA integrity (RIN) and PMI were not significantly different between groups.

Frozen tissue was processed using Biosafety Level 2+ (BL2+) procedures approved by the Beth Israel Deaconess Medical Center (BIDMC) Institutional Biosafety Committee (IBC). Brain tissues were homogenized using Trizol (Thermo Fisher) reagent and RNA extracted by phase separation. Total RNA was quantified by nanodrop (DeNovix DS-11) and TapeStation 4200 (RNA Screen Tape; Agilent Technologies, Inc). 
medRxiv preprint doi: https://doi.org/10.1101/2021.11.24.21266779; this version posted November 24, 2021. The copyright holder for this preprint (which was not certified by peer review) is the author/funder, who has granted medRxiv a license to display the preprint in perpetuity.

It is made available under a CC-BY-NC-ND 4.0 International license .

\section{Library construction and RNA-sequencing}

$232450 \mathrm{ng}$ of total RNA was used for library preparation via the KAPA RNA HyperPrep kit with

233 RiboErase (HMR; Roche) according to the manufacturer's recommendations. Briefly,

234 hybridization with hybridization oligos (HMR) was performed at $95^{\circ} \mathrm{C}$ for 2 min followed by rRNA

235 depletion using RNAse $\mathrm{H}$ which was performed at $45^{\circ} \mathrm{C}$ for 30 min. Following rRNA cleanup via

236 KAPA pure beads, DNase digestion was performed at $37^{\circ} \mathrm{C}$ for 30 min followed by cleanup, RNA

237 elution, fragmentation $\left(6 \min\right.$ at $94^{\circ} \mathrm{C}$ for samples with $\mathrm{RIN} \geq 7$ or 5 min at $85^{\circ} \mathrm{C}$ for samples with

238 RIN $\leq 7$ ), and priming. First and second strand synthesis and A-tailing were performed according

239 to manufacturer's recommendations. 1.5 $\mu \mathrm{M}$ KAPA Unique Dual-Indexed (UDI; Roche) adapters

240 were ligated to the second strand synthesis product in the presence of a ligation master mix in a

241 reaction that was performed at $20{ }^{\circ} \mathrm{C}$ for $15 \mathrm{~min}$. Following cleanup, all libraries underwent 10

242 cycles of amplification. Successful library production, quality control, and quantification was

243 assessed using Tapestation (High sensitivity D1000 Screen Tape; Agilent Technologies, Inc). All

244 libraries were pooled together (10 nM concentration) and subjected to two lanes of a NovaSeq

2456000.

246 RT-qPCR (qPCR)

247 A total of $400 \mathrm{ng}$ RNA from each sample was processed for cDNA via SuperScript IV Reverse

248 Transcriptase kit (ThermoFisher Scientific) according to the manufacturer's instructions. All qPCR

249 experiments were performed in a 384-well plate using LightCycler 480 SYBR Green via a Roche

250 LightCycler 480 II PCR system.

To assess the expression of SARS-CoV-2, primers against the SARS-CoV-2 N1 and N2

252 genes were synthesized (IDT) as recommended by the US Center of Disease Control and

253 Prevention (CDC). The 2019-nCoV_N_Positive Control RUO Plasmid (IDT \#10006625) was

254 included as positive control. ITM2B (Qiagen) was used for normalization. Primers for S100A9, 
medRxiv preprint doi: https://doi.org/10.1101/2021.11.24.21266779; this version posted November 24, 2021. The copyright holder for this preprint (which was not certified by peer review) is the author/funder, who has granted medRxiv a license to display the preprint in perpetuity.

It is made available under a CC-BY-NC-ND 4.0 International license .

255

256

257 method [36].

\section{RNA-seq analysis}

259 For assessment of SARS-CoV-2 genome alignment: reads were aligned to the SARS-CoV-2 260

261

262

RHOBTB3, MYL12A, CALM3, INPP4A, GRIA1, and GRIN3A were designed to span exon-exon junctions using NIH Primer Blast and synthesized by IDT. qPCR data were analyzed via the $2^{-\Delta \Delta C t}$ reference genome (NCBI reference sequence NC_045512.2) using bowtie2 v2.2.9 with options “-X 1000 --no-mixed”. Analysis of RNA-seq of Calu-3 infected samples from Blanco-Melo et al. [37] were included as positive controls with default bowtie2 parameters.

For assessment of differential gene expression: raw sequencing reads were aligned to a reference transcriptome generated from the Ensembl v104 human transcriptome with salmon v1.4.0 using options “--seqBias --useVBOpt --gcBias --posBias --numBootstraps 30 -validateMappings". Length-scaled transcripts per million were acquired using the tximport v1.18.0 function, and log2 fold changes and false discovery rates (FDR) were determined by DESeq2 v1.30.1 in R. t-stochastic neighboring embedding analysis was performed using Rtsne v0.15, with counts transformed by the varianceStabilizingTransformation (VST) function from DESeq2. Heatmaps were generated using pheatmap v1.0.12 using VST-transformed counts, with further scaling across samples. For full cohort analysis, age/sex-matching was used as a covariate. For cohort subset analyses, no additional covariates were used.

\section{Gene set enrichment analysis}

Signed -log10 FDRs from DESeq2 analyses were used to rank genes for gene set enrichment analysis via fgsea v1.16.0, filtering out genes with an FDR $<0.5$. Public gene sets used for analyses: Gene Ontology Biological Processes (GO.db v3.12.1), KEGG (KEGGREST v1.30.1), and ReactomeDB (reactome.db v1.74.0) pathway to gene mappings from fgsea via the 
medRxiv preprint doi: https://doi.org/10.1101/2021.11.24.21266779; this version posted November 24, 2021. The copyright holder for this preprint (which was not certified by peer review) is the author/funder, who has granted medRxiv a license to display the preprint in perpetuity.

It is made available under a CC-BY-NC-ND 4.0 International license .

278 "reactomePathways" function. For enrichment analyses, Ensembl gene IDs were matched with

279 corresponding gene symbols and Entrez IDs via biomaRt v2.46.3.

280 Brain aging-regulated molecular signatures

281 We leveraged previously published aging-regulated differentially expressed gene (DEG) set data

282 generated in five independent cohorts [14, 21, 38-41]. Lu et al. (2004) performed a broad-

283 spectrum gene expression analysis (Affymetrix Human Genome U95Av2) of human prefrontal

284 cortex from 30 individuals 26-106 years old and determined age-regulated genes based on a 285 comparison of individuals $\leq 42$ vs individuals $\geq 73$ years old [14]. Loerch et al. (2008) performed 286 a genome-wide gene expression analysis (Affymetrix Human Genome U133plus 2.0) of human 287 prefrontal cortex from 28 individuals 24-94 years old and determined age-regulated genes based 288 on a comparison of individuals $\leq 40$ vs individuals $\geq 70$ years old [21]. For three additional human 289 patient cohorts, we used differentially expressed genes as performed by [42] in which gene 290 expression data from individuals 85+ years old were compared to gene expression data of 291 younger individuals, including only individuals with annotated normal cognitive function. Those 292 cohorts include 1) the Gibbs et al. cohort [38] in which gene expression data (Illumina HumanRef2938 Expression BeadChips) from the frontal cortex of 37 individuals were analyzed and DEGs 294 estimated by comparing individuals $85+$ to individuals $55-80$ years old [42]; 2) the ROSMAP 295 cohort, part of the Religious Order Study (ROS) and Rush Memory and Aging Project (MAP; 296 ROSMAP) at the Rush Alzheimer's Disease Center [40, 41, 43], in which RNA-seq data from the 297 dorsolateral prefrontal cortex of 117 individuals were analyzed and DEGs estimated by comparing 298 individuals 85+ to individuals 70-80 years old [42]; and 3) the Common Mind Consortium (CMC) 299 cohort [39] in which RNA-seq data from the dorsolateral prefrontal cortex of 155 individuals were 300 analyzed and DEGs estimated by comparing individuals $85+$ to individuals $60-80$ years old [42]. 
medRxiv preprint doi: https://doi.org/10.1101/2021.11.24.21266779; this version posted November 24, 2021. The copyright holder for this preprint (which was not certified by peer review) is the author/funder, who has granted medRxiv a license to display the preprint in perpetuity.

It is made available under a CC-BY-NC-ND 4.0 International license .

302

303 No statistical methods were used to predetermine sample size. The experimental groups were 304 not randomized. Where possible, samples were processed together using deidentified numbers 305 (RNA-seq library preparation, reverse transcription prior to qPCR, and qPCR). For qPCR and 306 RNA-seq analyses, blinding was not possible as all changes had to be matched with

\section{Statistical analysis}

corresponding controls. qPCR data were analyzed with a two-tailed t-test via GraphPad Prism 9. RNA-seq statistical analyses were performed in R v4.0.4 [44].

\section{Data availability}

RNA-seq fastq files generated for this study are available through GEO with accession number GSE188847. Raw Calu-3 .fastq RNA-seq files from Blanco-Melo et al. are available through GEO (https://www.ncbi.nlm.nih.gov/geo/query/acc.cgi?acc=GSE147507) with accession numbers GSM4462348-GSM4462353 [37].

The SARS-CoV-2 genome was obtained from https://www.ncbi.nlm.nih.gov/nuccore/1798174254. The Ensembl v104 human reference transcriptome was obtained from http://ftp.ensembl.org/pub/release104/fasta/homo sapiens/cdna/Homo sapiens.GRCh38.cdna.all.fa.gz. Gene Ontology (http://geneontology.org/) was queried from org.Hs.eg.db v3.12.0 in R. Reactome pathway annotations (https://reactome.org/) were obtained via the "reactomePathways" command in $\mathrm{R}$ package "fgsea": https://bioconductor.org/packages/release/bioc/html/fgsea.html. KEGG hsa pathway annotations (https://www.genome.jp/kegg/) were obtained using the KEGGREST v1.30.1 API in R (https://www.bioconductor.org/packages/release/bioc/html/KEGGREST.html). 
medRxiv preprint doi: https://doi.org/10.1101/2021.11.24.21266779; this version posted November 24, 2021. The copyright holder for this preprint (which was not certified by peer review) is the author/funder, who has granted medRxiv a license to display the preprint in perpetuity.

It is made available under a CC-BY-NC-ND 4.0 International license.

\section{References}

326 1. Solomon, I.H., et al., Neuropathological Features of Covid-19. N Engl J Med, 2020.

$327 \quad 383(10):$ p. $989-992$

328 2. Helms, J., et al., Neurologic Features in Severe SARS-CoV-2 Infection. N Engl J Med, 2020. 382(23): p. 2268-2270.

330

3. Hampshire, A., et al., Cognitive deficits in people who have recovered from COVID-19. EClinicalMedicine, 2021. 39: p. 101044.

4. Delorme, C., et al., COVID-19-related encephalopathy: a case series with brain FDGpositron-emission tomography/computed tomography findings. Eur J Neurol, 2020. 27(12): p. 2651-2657.

5. Kas, A., et al., The cerebral network of COVID-19-related encephalopathy: a longitudinal voxel-based 18F-FDG-PET study. Eur J Nucl Med Mol Imaging, 2021. 48(8): p. 25432557.

6. Miller, E.K., The prefrontal cortex and cognitive control. Nat Rev Neurosci, 2000. 1(1): p. 59-65. 2004. 306(5695): p. 443-7.

8. ladecola, C., J. Anrather, and H. Kamel, Effects of COVID-19 on the Nervous System. Cell, 2020. 183(1): p. 16-27 e1.

9. Hosp, J.A., et al., Cognitive impairment and altered cerebral glucose metabolism in the subacute stage of COVID-19. Brain, 2021. 144(4): p. 1263-1276.

10. Douaud, G., et al., Brain imaging before and after COVID-19 in UK Biobank. medRxiv, 2021.

11. Nyberg, L., et al., Longitudinal evidence for diminished frontal cortex function in aging. 
medRxiv preprint doi: https://doi.org/10.1101/2021.11.24.21266779; this version posted November 24, 2021. The copyright holder for this preprint (which was not certified by peer review) is the author/funder, who has granted medRxiv a license to display the preprint in perpetuity.

It is made available under a CC-BY-NC-ND 4.0 International license .

350

351

352

353

354

355

356

357

358

359

360

361

362

363

364

365

366

367

368

369

370

371

372

373

374

12. Bishop, N.A., T. Lu, and B.A. Yankner, Neural mechanisms of ageing and cognitive decline. Nature, 2010. 464(7288): p. 529-35.

13. Ham, S. and S.V. Lee, Advances in transcriptome analysis of human brain aging. Exp Mol Med, 2020. 52(11): p. 1787-1797.

14. Lu, T., et al., Gene regulation and DNA damage in the ageing human brain. Nature, 2004. 429(6994): p. 883-91.

15. Konar, A., P. Singh, and M.K. Thakur, Age-associated Cognitive Decline: Insights into Molecular Switches and Recovery Avenues. Aging Dis, 2016. 7(2): p. 121-9.

16. Yang, A.C., et al., Dysregulation of brain and choroid plexus cell types in severe COVID19. Nature, 2021. 595(7868): p. 565-571.

17. Fullard, J.F., et al., Single-nucleus transcriptome analysis of human brain immune response in patients with severe COVID-19. Genome Med, 2021. 13(1): p. 118.

18. Saheb Sharif-Askari, N., et al., Upregulation of oxidative stress gene markers during SARS-COV-2 viral infection. Free Radic Biol Med, 2021. 172: p. 688-698.

19. Silvin, A., et al., Elevated Calprotectin and Abnormal Myeloid Cell Subsets Discriminate Severe from Mild COVID-19. Cell, 2020. 182(6): p. 1401-1418 e18.

20. Prelli Bozzo, C., et al., IFITM proteins promote SARS-CoV-2 infection and are targets for virus inhibition in vitro. Nat Commun, 2021. 12(1): p. 4584.

21. Loerch, P.M., et al., Evolution of the aging brain transcriptome and synaptic regulation. PLoS One, 2008. 3(10): p. e3329.

22. Yousefzadeh, M., et al., DNA damage-how and why we age? Elife, 2021.10.

23. Pollack, M., et al., The role of apoptosis in the normal aging brain, skeletal muscle, and heart. Ann N Y Acad Sci, 2002. 959: p. 93-107.

24. Boehm, M. and F. Slack, A developmental timing microRNA and its target regulate life span in C. elegans. Science, 2005. 310(5756): p. 1954-7. 
medRxiv preprint doi: https://doi.org/10.1101/2021.11.24.21266779; this version posted November 24, 2021. The copyright holder for this preprint (which was not certified by peer review) is the author/funder, who has granted medRxiv a license to display the preprint in perpetuity.

It is made available under a CC-BY-NC-ND 4.0 International license .

25. Cholerton, B., L.D. Baker, and S. Craft, Insulin resistance and pathological brain ageing. Diabet Med, 2011. 28(12): p. 1463-75.

26. Smith-Vikos, T., et al., MicroRNAs mediate dietary-restriction-induced longevity through PHA-4/FOXA and SKN-1/Nrf transcription factors. Curr Biol, 2014. 24(19): p. 2238-46.

27. Primiani, C.T., et al., Coordinated gene expression of neuroinflammatory and cell signaling markers in dorsolateral prefrontal cortex during human brain development and aging. PLoS One, 2014. 9(10): p. e110972.

28. Chapman, T.R., et al., Aging and infection reduce expression of specific brain-derived neurotrophic factor mRNAs in hippocampus. Neurobiol Aging, 2012. 33(4): p. 832 e1-14.

29. Soreq, L., et al., Major Shifts in Glial Regional Identity Are a Transcriptional Hallmark of Human Brain Aging. Cell Rep, 2017. 18(2): p. 557-570.

30. Gagliardi, S., et al., Detection of SARS-CoV-2 genome and whole transcriptome sequencing in frontal cortex of COVID-19 patients. Brain Behav Immun, 2021.

31. Mikkelsen, M.E., et al., The adult respiratory distress syndrome cognitive outcomes study: long-term neuropsychological function in survivors of acute lung injury. Am J Respir Crit Care Med, 2012. 185(12): p. 1307-15.

32. Lee, M.H., et al., Microvascular Injury in the Brains of Patients with Covid-19. N Engl J Med, 2021. 384(5): p. 481-483.

33. Hou, Y., et al., Ageing as a risk factor for neurodegenerative disease. Nat Rev Neurol, 2019. 15(10): p. 565-581.

34. Inukai, S., et al., Novel microRNAs differentially expressed during aging in the mouse brain. PLoS One, 2012. 7(7): p. e40028.

35. Livingston, G., et al., Dementia prevention, intervention, and care: 2020 report of the Lancet Commission. Lancet, 2020. 396(10248): p. 413-446.

36. Schmittgen, T.D. and K.J. Livak, Analyzing real-time PCR data by the comparative $C(T)$ method. Nat Protoc, 2008. 3(6): p. 1101-8. 
medRxiv preprint doi: https://doi.org/10.1101/2021.11.24.21266779; this version posted November 24, 2021. The copyright holder for this preprint (which was not certified by peer review) is the author/funder, who has granted medRxiv a license to display the preprint in perpetuity.

It is made available under a CC-BY-NC-ND 4.0 International license .

401 37. Blanco-Melo, D., et al., Imbalanced Host Response to SARS-CoV-2 Drives Development

402 of COVID-19. Cell, 2020. 181(5): p. 1036-1045 e9.

403 38. Gibbs, J.R., et al., Abundant quantitative trait loci exist for DNA methylation and gene $404 \quad$ expression in human brain. PLoS Genet, 2010. 6(5): p. e1000952.

405 39. Fromer, M., et al., Gene expression elucidates functional impact of polygenic risk for 406 schizophrenia. Nat Neurosci, 2016. 19(11): p. 1442-1453.

407 40. Bennett, D.A., et al., Overview and findings from the rush Memory and Aging Project. Curr 408 Alzheimer Res, 2012. 9(6): p. 646-63.

409 41. Bennett, D.A., et al., Overview and findings from the religious orders study. Curr Alzheimer 410 Res, 2012. 9(6): p. 628-45.

411 42. Zullo, J.M., et al., Regulation of lifespan by neural excitation and REST. Nature, 2019. 574(7778): p. 359-364.

413 43. De Jager, P.L., et al., A multi-omic atlas of the human frontal cortex for aging and Alzheimer's disease research. Sci Data, 2018. 5: p. 180142.

415 44. Team, R.C., R: A language and environment for statistical computing. 2018, Vienna: R 416 Foundation for Statistical Computing. 
medRxiv preprint doi: https://doi.org/10.1101/2021.11.24.21266779; this version posted November 24, 2021. The copyright holder for this preprint (which was not certified by peer review) is the author/funder, who has granted medRxiv a license to display the preprint in perpetuity.

a
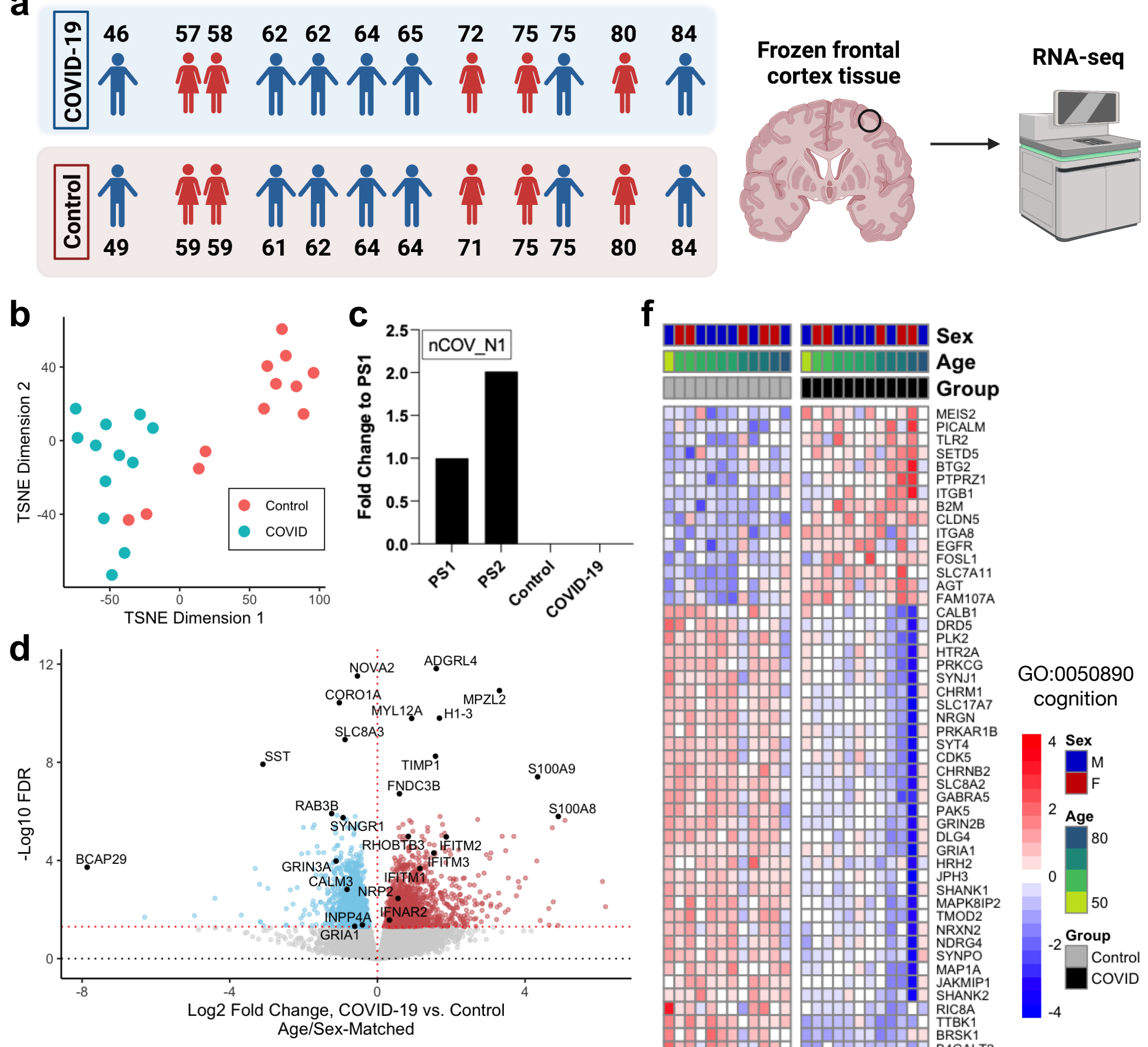

f
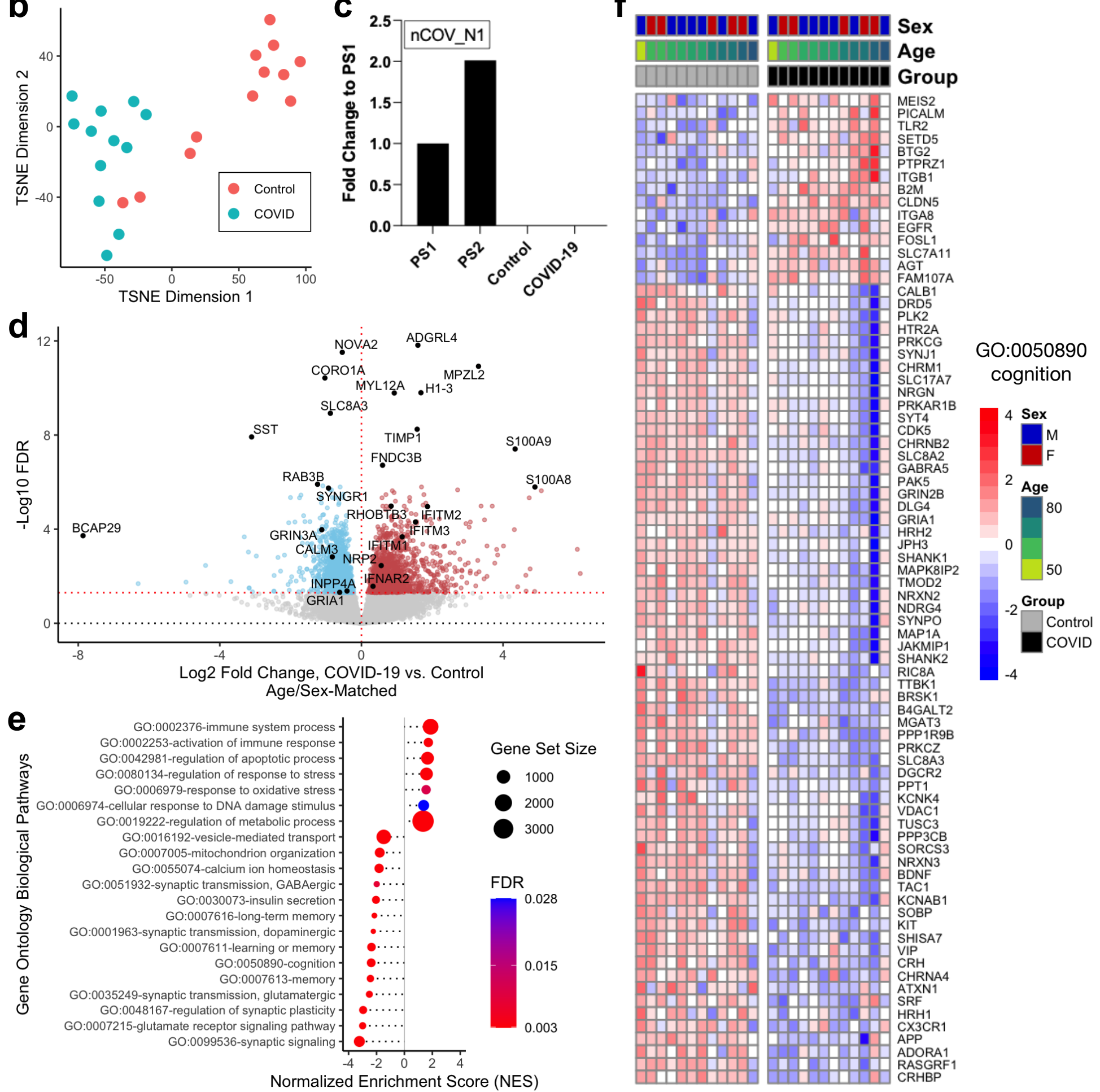
medRxiv preprint doi: https://doi.org/10.1101/2021.11.24.21266779; this version posted November 24, 2021. The copyright holder for this preprint (which was not certified by peer review) is the author/funder, who has granted medRxiv a license to display the preprint in perpetuity.

It is made available under a CC-BY-NC-ND 4.0 International license .

422 Fig 1. Severe COVID-19 induces global transcriptomic changes in the frontal cortex of the

423 brain. a. Left, age and sex of each individual in COVID-19 or control groups ( $n=12 /$ group)

424 analyzed in this cohort. Each COVID-19 case was matched with an uninfected control case by

425 sex and age ( \pm 2 years). Right, schematic of study approach. Schematic was generated with

426 BioRender. b. t-distributed stochastic neighbor embedding (TSNE) analysis of frontal cortex

427 transcriptomes from COVID-19 cases and uninfected controls. c. qPCR assessment of SARS-

428 CoV-2 viral RNA in the frontal cortex using the nCOV_N1 primer set. PS1 and PS2 correspond

429 to the 2019-nCoV_N_Positive Control RUO Plasmid (IDT) at concentrations of 1,000 and 2,000

430 copies/ $\mu \mathrm{l}$, respectively (a technical duplicate/concentration was used to estimate the

431 corresponding mean; for control and COVID-19 samples $n=13 /$ group). d. Volcano plot

432 representing the differentially expressed genes (DEGs) of the frontal cortex of COVID-19 cases

433 versus matched controls. Red points, significantly upregulated genes among COVID-19 cases

434 (false discovery rate $<0.05$ ). Blue points, significantly downregulated genes among COVID-19

435 cases. Black points, highlighted significant genes with corresponding gene symbols. e. Gene

436 ontology (GO) biological pathway enrichment analysis of COVID-19 versus control brain DEGs.

437 Gene ranks were determined by signed -log10 false discovery rates of DEGs. FDR, gene set

438 enrichment analysis false discovery rate. f. Heatmap of relative gene expression levels of

439 significant DEGs associated with the "cognition" (GO: 0050890) GO term across COVID-19 and

440 control samples. Color legend, scaled gene expression levels across subjects, normalized via

441 variance-stabilized transformation. 
medRxiv preprint doi: https://doi.org/10.1101/2021.11.24.21266779; this version posted November 24, 2021. The copyright holder for this preprint (which was not certified by peer review) is the author/funder, who has granted medRxiv a license to display the preprint in perpetuity.

It is made available under a CC-BY-NC-ND 4.0 International license .

a

Postmortem human frontal cortex

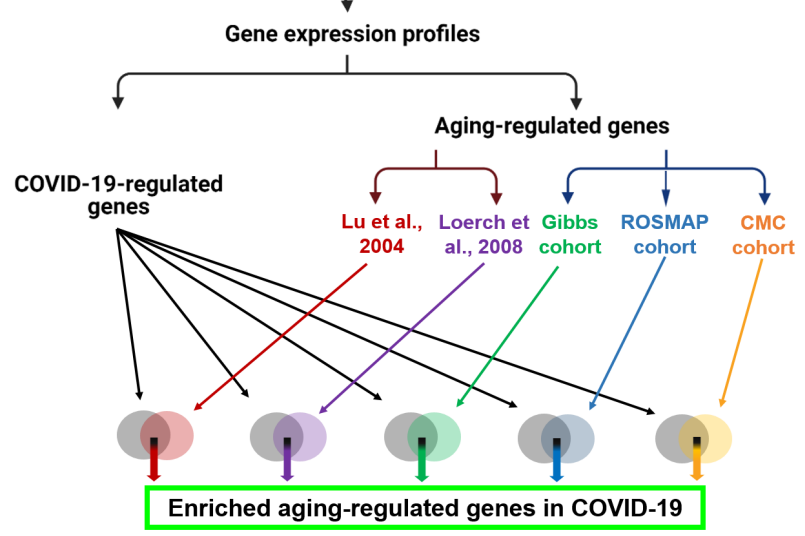

d

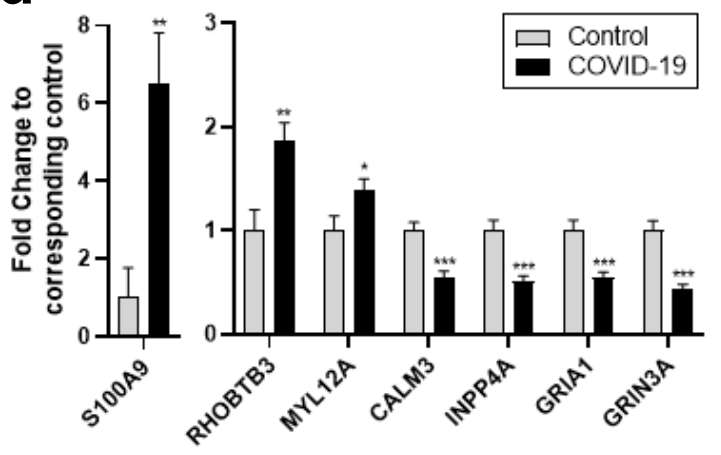

g
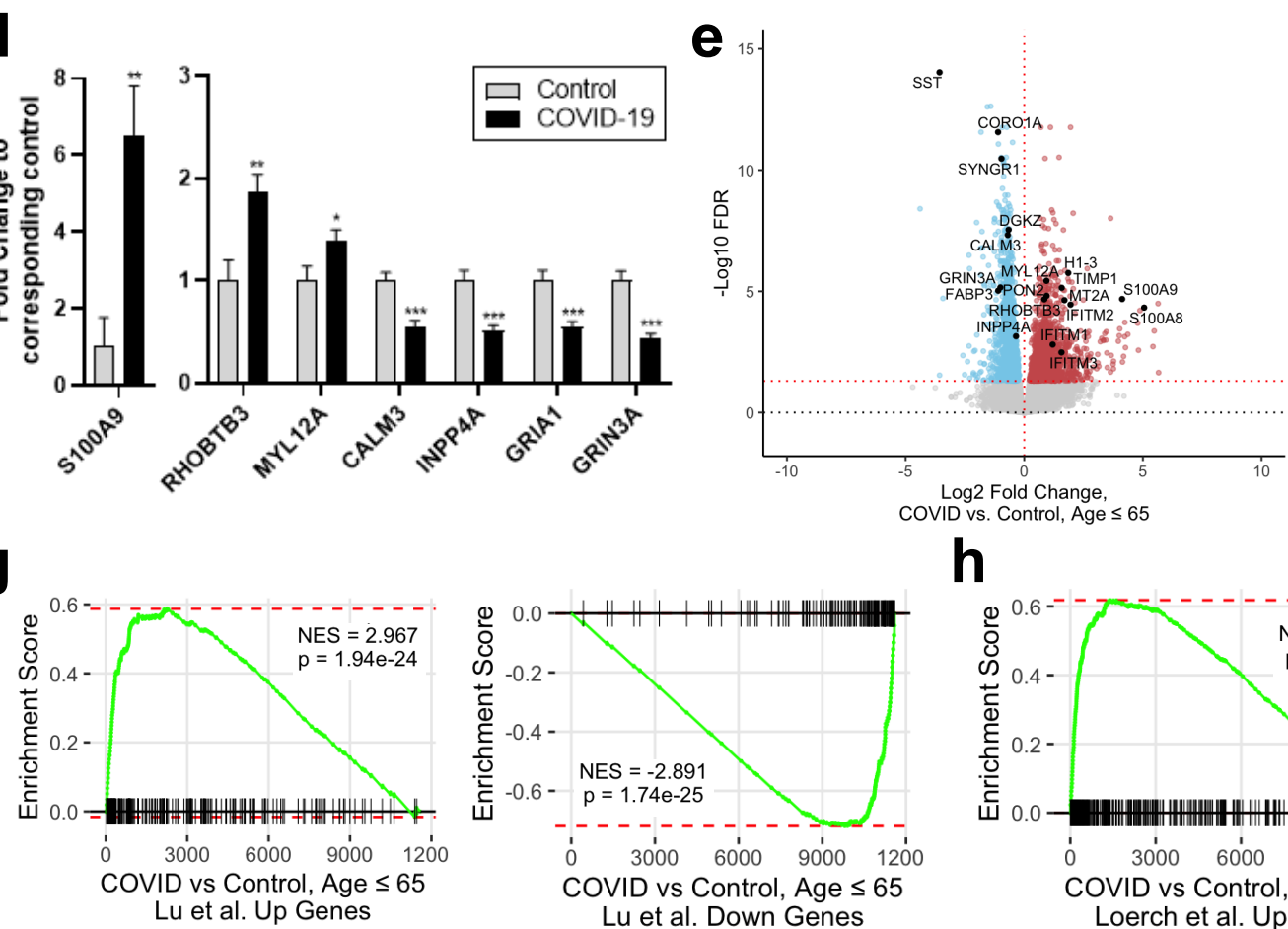

h

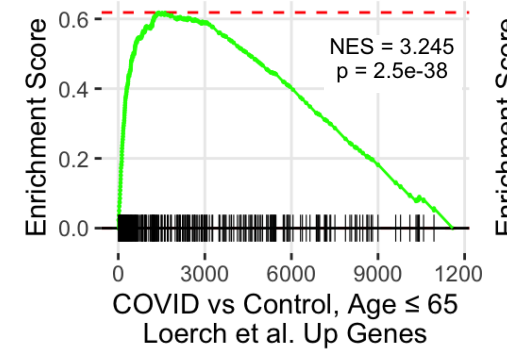

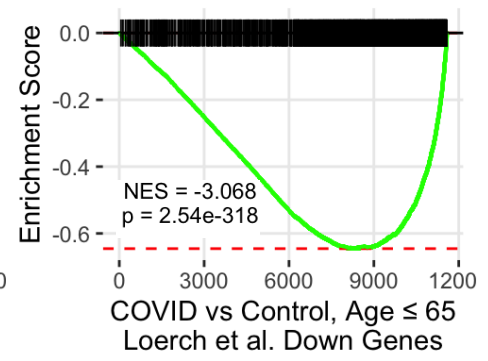
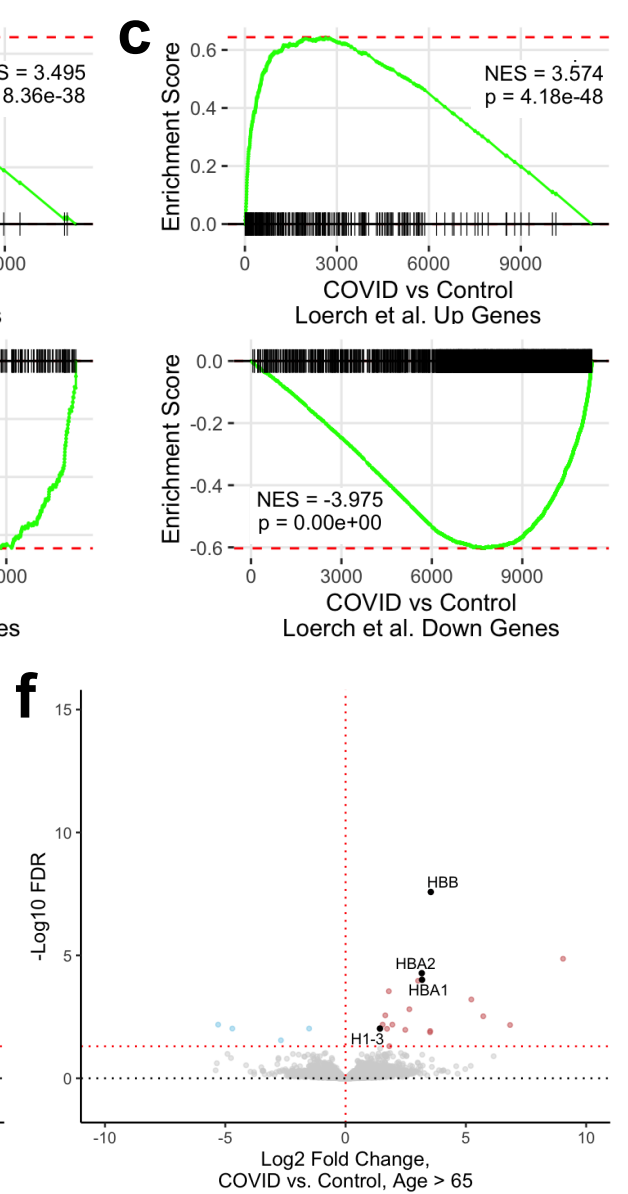

Log2 Fold Change,
COVID vs. Control, Age >

Loerch et al. Down Genes 
medRxiv preprint doi: https://doi.org/10.1101/2021.11.24.21266779; this version posted November 24, 2021. The copyright holder for this preprint (which was not certified by peer review) is the author/funder, who has granted medRxiv a license to display the preprint in perpetuity.

It is made available under a CC-BY-NC-ND 4.0 International license .

444

445

446

447

448

449

450

451

452

453

454

455

456

457

458

459

460

461

462

463

464

\section{Fig 2. Severe COVID-19 induces transcriptomic signatures of aging in the human brain. a.} COVID-19-associated DEGs were assessed for enrichment of brain aging DEGs curated from each of five independent patient cohort studies (Lu et al., 2004, n=21 [14]; Loerch et al., 2008, $\mathrm{n}=28$ [21]; Gibbs cohort, $\mathrm{n}=37$ [38, 42]; ROSMAP cohort, $\mathrm{n}=117$ [40-43], Common Mind Consortium/CMC cohort, $n=155[39,42]$; $n$ refers to the number of individuals analyzed in each cohort). Schematic was generated with BioRender. b and c. Gene set enrichment analysis of COVID-19 DEGs, using significantly up- (top) or down-regulated genes (bottom) in the Lu et al. (2004) (b) and Loerch et al. (2008) (c) cohorts as gene sets. DEG ranks were assigned by signed - $\log 10$ false discovery rates from COVID-19 versus control frontal cortex. NES, normalized enrichment score. p, GSEA p-value. See also Supplementary Fig. 5. d. qPCR assessment of candidate COVID-19 DEGs associated with aging ( $\mathrm{n}=13 /$ group). ${ }^{*} p<0.05 ;{ }^{* *} p<0.01 ;{ }^{* * *} p<0.001$. Data are expressed as fold change relative to control \pm SEM. e and f. Volcano plots representing the DEGs of the frontal cortex of COVID-19 cases versus controls among patients $\leq 65$ (e, $\mathrm{n}=7$ /group) or $>65$ (f, $n=5 /$ group) years of age. Red points, significantly upregulated genes among COVID-19 cases (false discovery rate $<0.05$ ). Blue points, significantly downregulated genes among COVID-19 cases. Black points, significant genes with corresponding gene symbols. $\mathbf{g}$ and h. Gene set enrichment analysis of COVID-19 DEGs among individuals $\leq 65$ years of age, using significantly up- (left) or down-regulated genes (right) in the Lu et al. (2004) (g) and Loerch et al. (2008) (h) cohorts as gene sets. DEG ranks were assigned by signed -log10 FDR values from COVID-19 versus control brains among individuals $\leq 65$ years of age. NES, normalized enrichment score. p, GSEA p-value. See also Supplementary Fig. 7. 
medRxiv preprint doi: https://doi.org/10.1101/2021.11.24.21266779; this version posted November 24, 2021. The copyright holder for this preprint (which was not certified by peer review) is the author/funder, who has granted medRxiv a license to display the preprint in perpetuity.

It is made available under a CC-BY-NC-ND 4.0 International license .

a

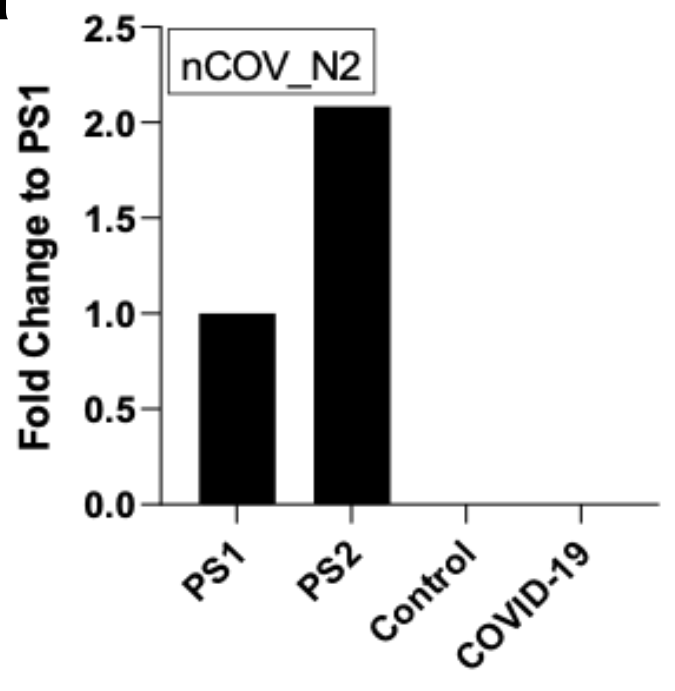

b

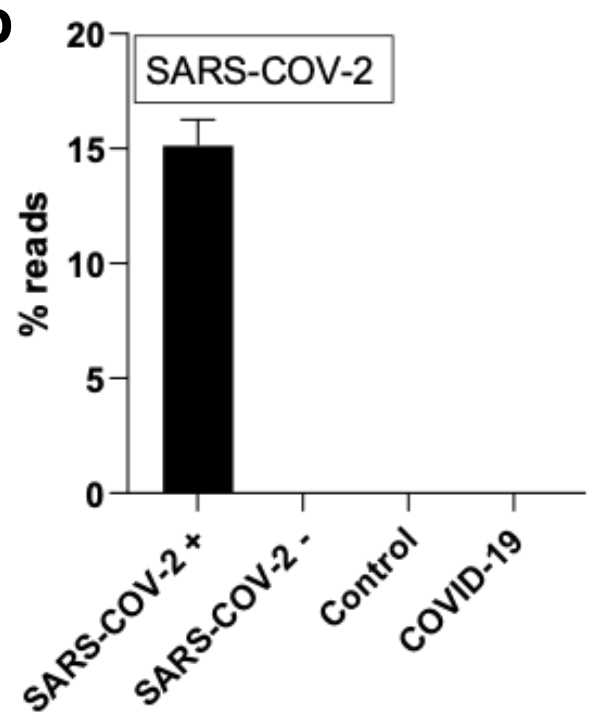


medRxiv preprint doi: https://doi.org/10.1101/2021.11.24.21266779; this version posted November 24, 2021. The copyright holder for this preprint (which was not certified by peer review) is the author/funder, who has granted medRxiv a license to display the preprint in perpetuity.

It is made available under a CC-BY-NC-ND 4.0 International license .

466 Supplementary Figure 1. Assessment of SARS-CoV-2 virus in the postmortem human

467 frontal cortex and expression of SARS-CoV-2 brain entry-related genes. a. qPCR

468 assessment of SARS-CoV-2 viral RNA in the frontal cortex using the nCOV_N2 primer set. PS1

469 and PS2 correspond to the 2019-nCoV_N_Positive Control RUO Plasmid (IDT) at concentrations

470 of 1,000 and 2,000 copies/ $\mu \mathrm{l}$, respectively (a technical duplicate/concentration was used to

471 estimate the corresponding mean; for control and COVID-19 samples $\mathrm{n}=13 /$ group). b.

472 Percentages of RNA-seq reads aligning to the SARS-CoV-2 viral genome. SARS-COV-2 + and

473 SARS-COV-2 - correspond to Calu-3 lung cancer cell lines either infected with SARS-CoV-2 virus

474 or mock-infected, respectively [37] ( $n=3 /$ group for the cell lines and $n=12$ for the control and

475 COVID-19 groups).

476

477 
medRxiv preprint doi: https://doi.org/10.1101/2021.11.24.21266779; this version posted November 24, 2021. The copyright holder for this preprint (which was not certified by peer review) is the author/funder, who has granted medRxiv a license to display the preprint in perpetuity.

a

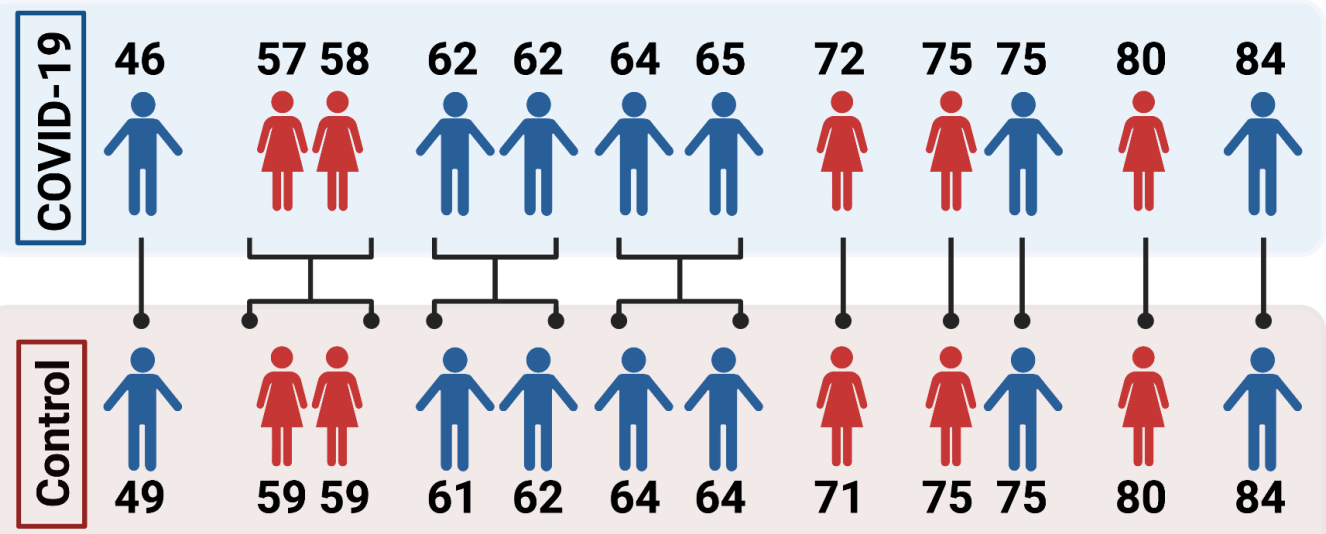

b
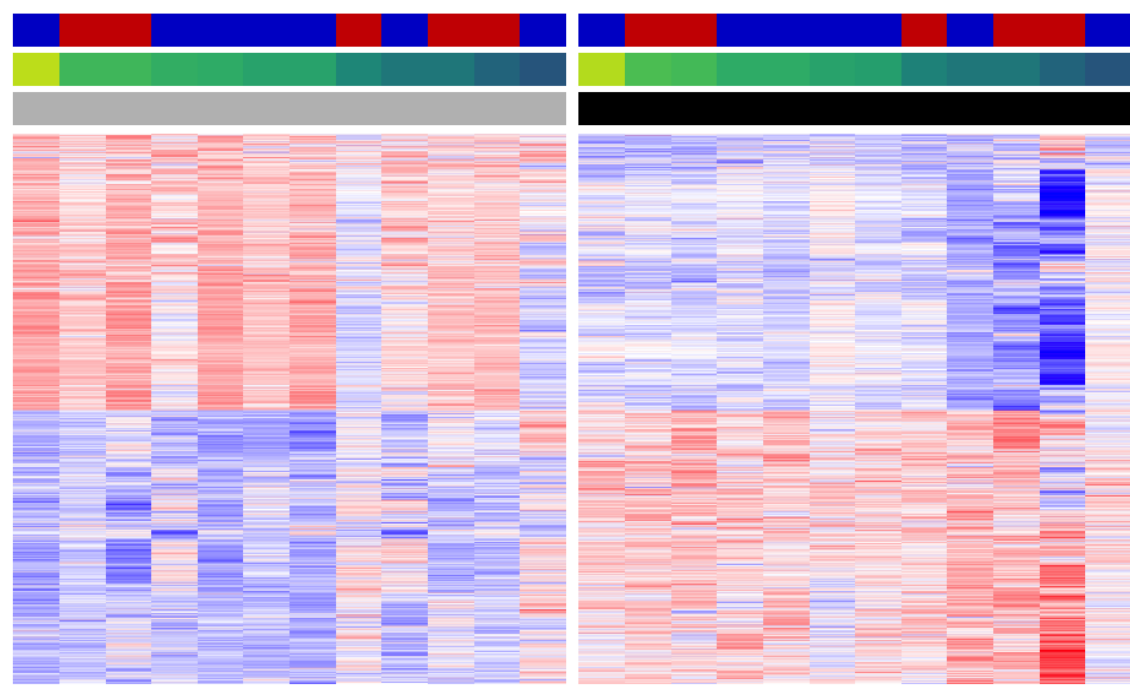

Sex

Age

Group

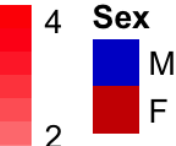

Age

0

80

$-2$

50

Group

$-4 \quad$ Control
COVID

C

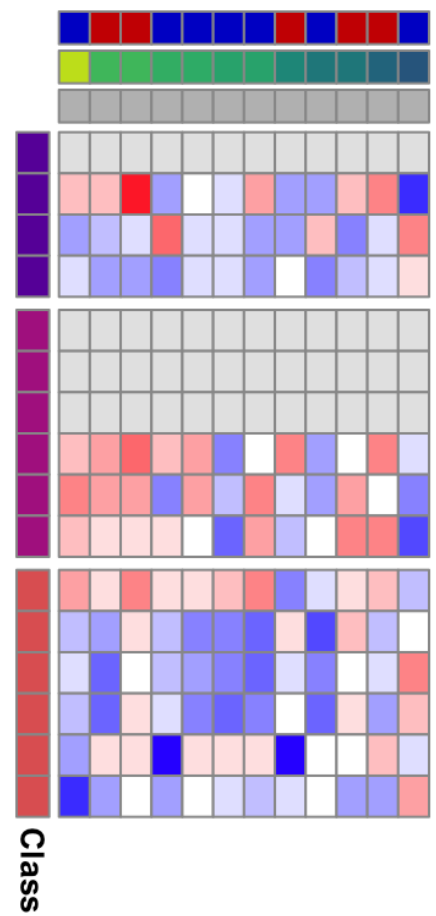

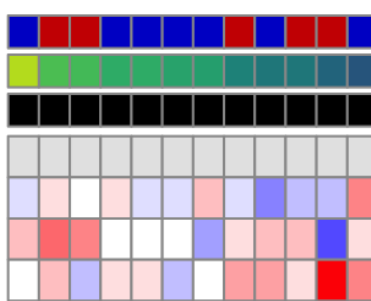
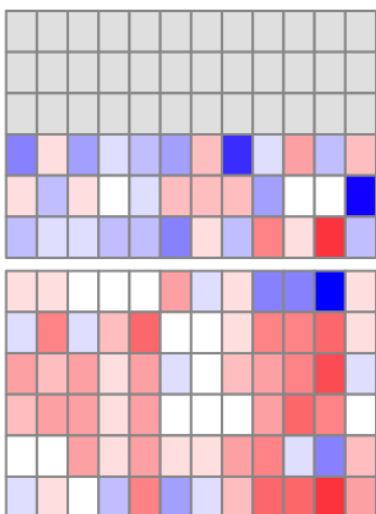

Sex

Age

Group

ACE2

BSG

NRP1

NRP2

TMPRSS2

TMPRSS11A

TMPRSS11B

FURIN

CTSB

CTSL

LY6E

IFITM1

IFITM2

IFITM3

IFNAR1

IFNAR2 $\begin{array}{lll}3 & \text { Sex } \\ & & \\ 2 & & \end{array}$

1 Age

$0 \quad 80$

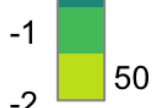

$-2$

Group

3 Control

Class

Docking

Processing

Viral Defense 
medRxiv preprint doi: https://doi.org/10.1101/2021.11.24.21266779; this version posted November 24, 2021. The copyright holder for this preprint (which was not certified by peer review) is the author/funder, who has granted medRxiv a license to display the preprint in perpetuity.

It is made available under a CC-BY-NC-ND 4.0 International license .

478 Supplementary Figure 2. Overview of differential expression patterns in frontal cortex of

479 COVID-19 and uninfected subjects. a. Age and sex matching used for differential expression

480 analysis. b. Heatmap of relative gene expression levels of all significant DEGs (FDR $<0.05)$

481 across COVID-19 and control samples. Color legend, scaled gene expression levels across

482 subjects, normalized via variance-stabilized transformation. c. Heatmap of relative expression

483 levels of genes previously implicated in SARS-CoV-2 viral entry in the human brain [8] across

484 COVID-19 and control samples. Color legend, scaled gene expression levels across patients,

485 normalized via variance-stabilized transformation. Light gray cells, no aligned reads or genes

486 filtered out of analysis. 
medRxiv preprint doi: https://doi.org/10.1101/2021.11.24.21266779; this version posted November 24, 2021. The copyright holder for this preprint (which was not certified by peer review) is the author/funder, who has granted medRxiv a license to display the preprint in perpetuity.

a

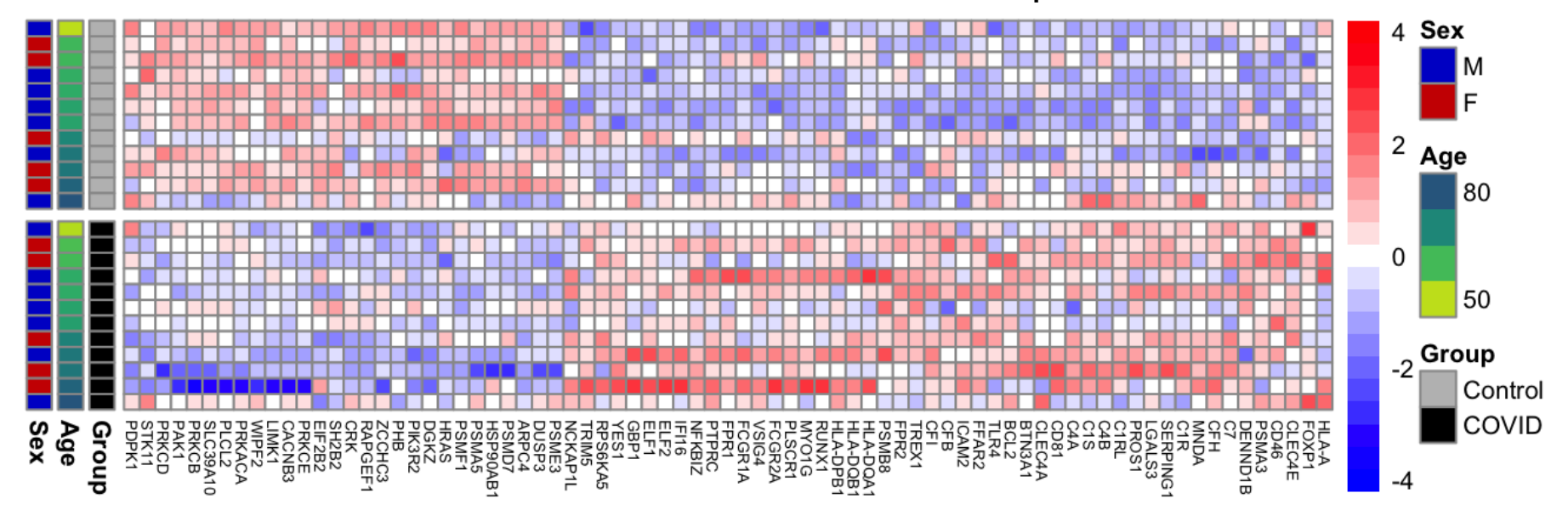

b

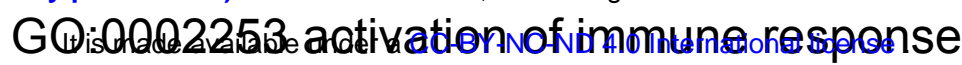

GO:0099536 synaptic signaling

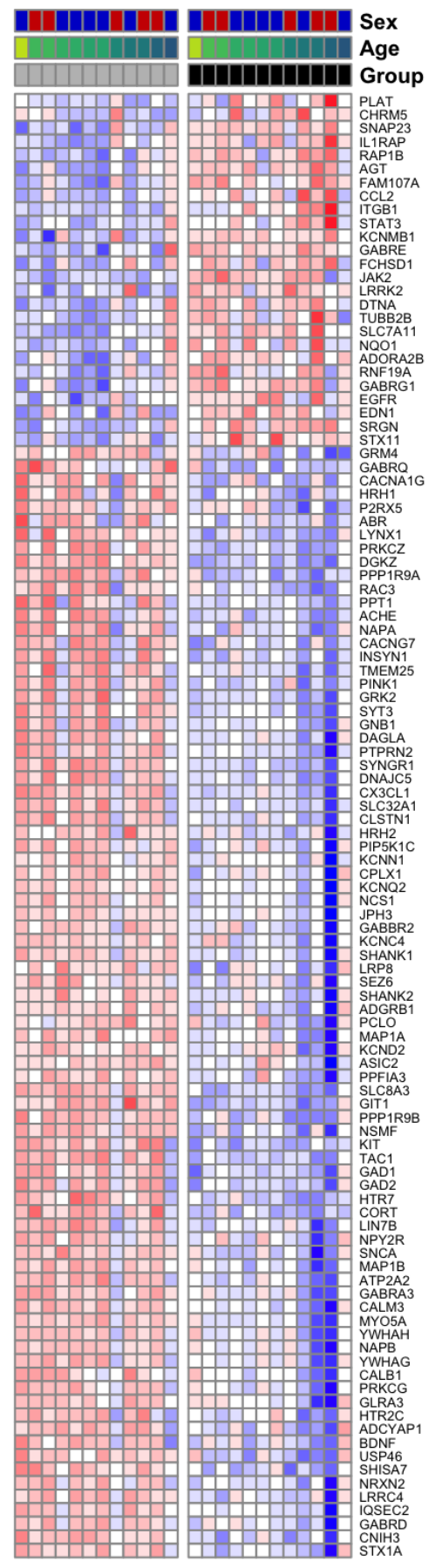

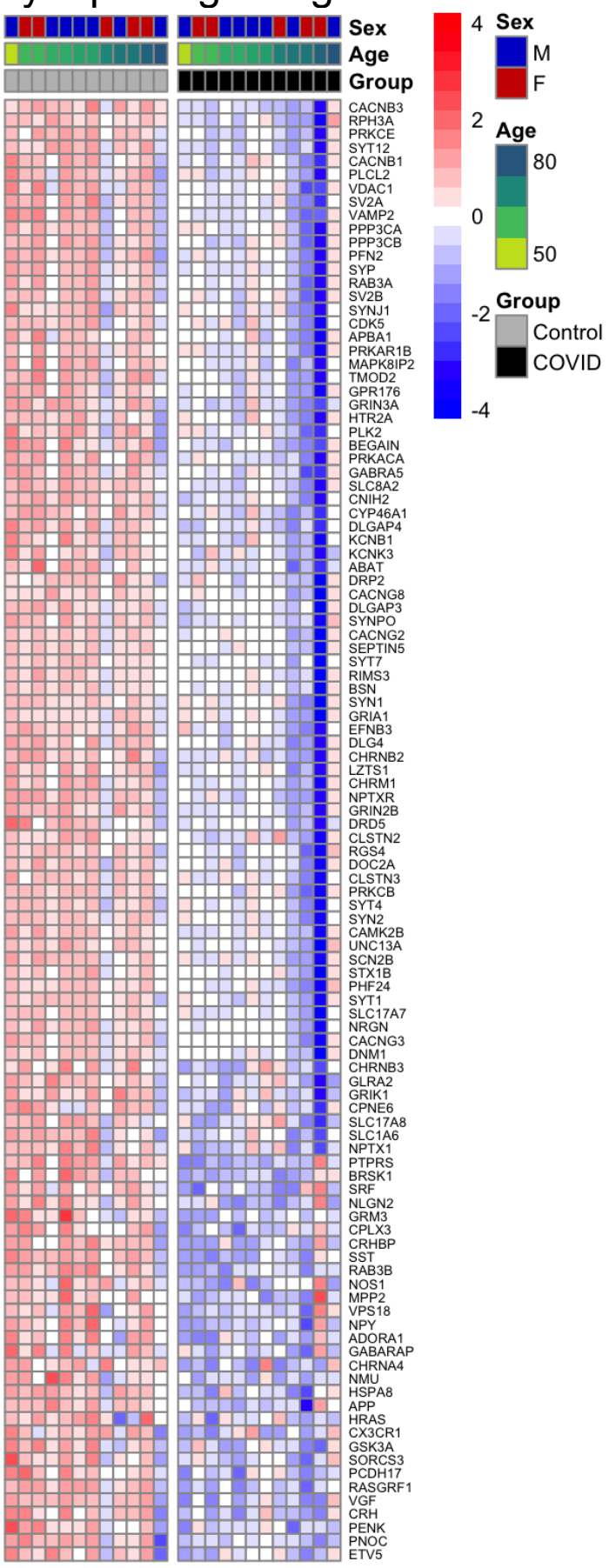

Supplementary Figure 3 
medRxiv preprint doi: https://doi.org/10.1101/2021.11.24.21266779; this version posted November 24, 2021. The copyright holder for this preprint (which was not certified by peer review) is the author/funder, who has granted medRxiv a license to display the preprint in perpetuity. It is made available under a CC-BY-NC-ND 4.0 International license.

489 Supplementary Figure 3. Gene expression patterns of immune response activation and

490 synaptic plasticity pathways. a and $\mathbf{b}$. Heatmaps of relative gene expression levels of

491 significant DEGs associated with "activation of immune response" (GO: 0002253) (a) or

492 "synaptic signaling" (GO: 0099536) (b) GO terms across COVID-19 and control samples. Color

493 legend, scaled gene expression levels across subjects, normalized via variance-stabilized

494 transformation.

495

496 
medRxiv preprint doi: https://doi.org/10.1101/2021.11.24.21266779; this version posted November 24, 2021. The copyright holder for this preprint (which was not certified by peer review) is the author/funder, who has granted medRxiv a license to display the preprint in perpetuity.

It is made available under a CC-BY-NC-ND 4.0 International license .

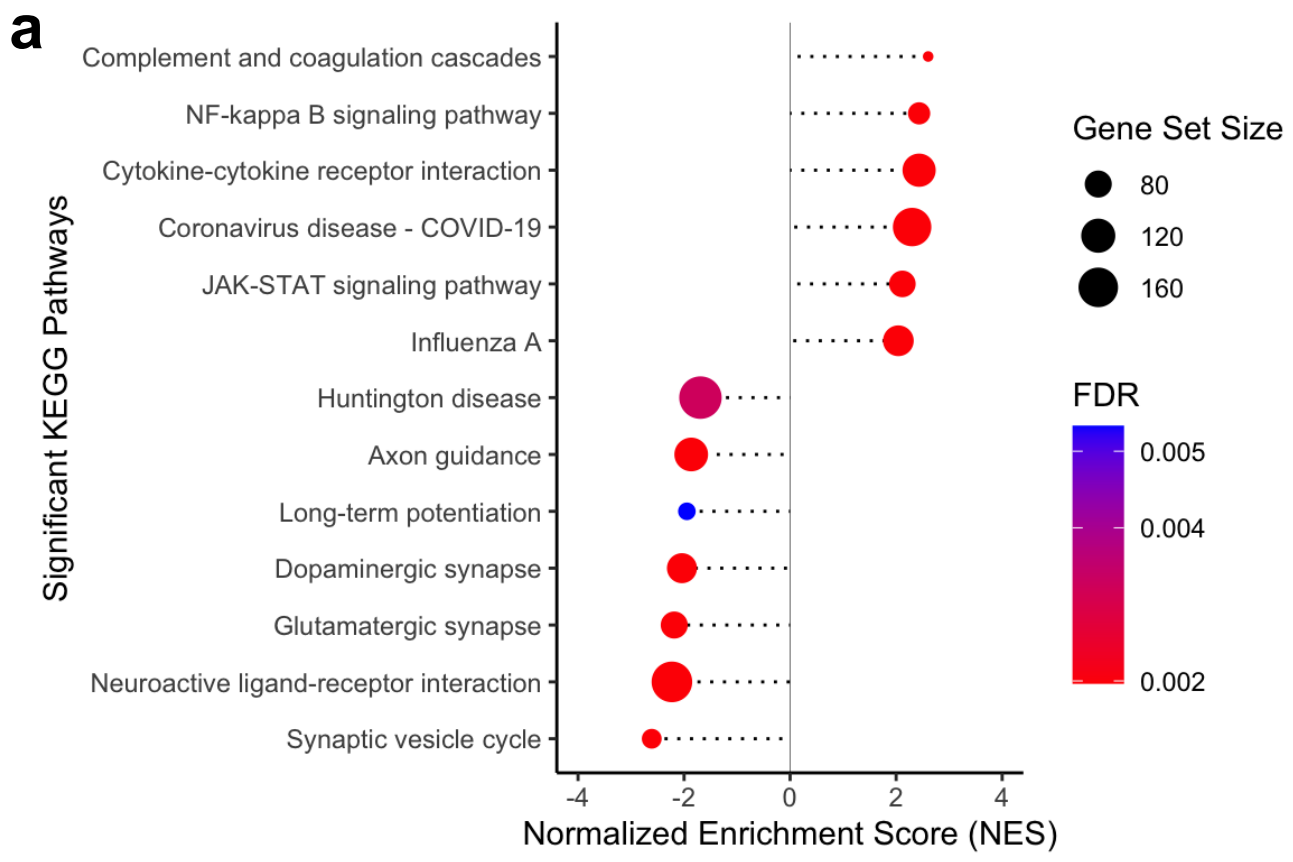

b

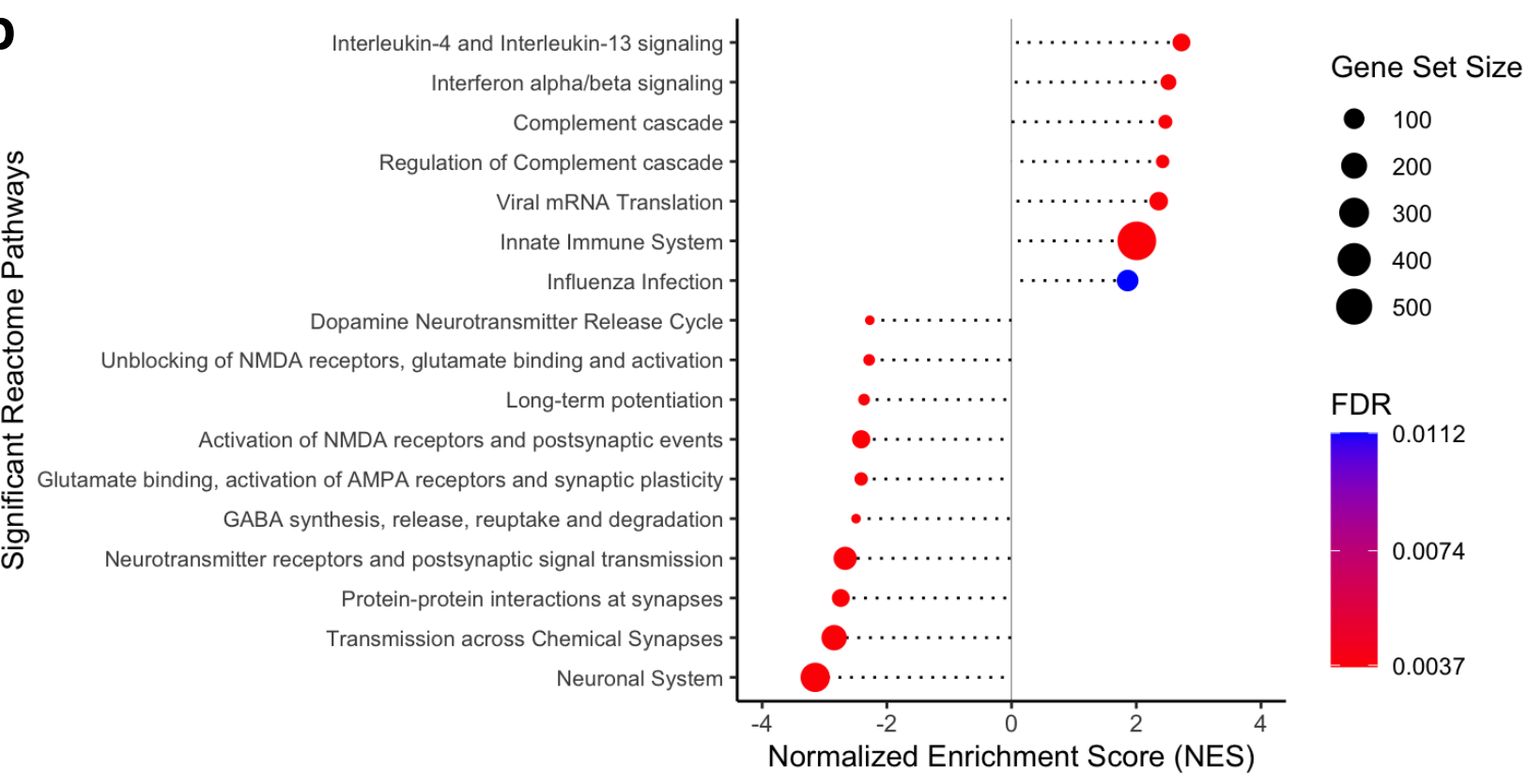


medRxiv preprint doi: https://doi.org/10.1101/2021.11.24.21266779; this version posted November 24, 2021. The copyright holder for this preprint (which was not certified by peer review) is the author/funder, who has granted medRxiv a license to display the preprint in perpetuity. It is made available under a CC-BY-NC-ND 4.0 International license.

497 Supplementary Figure 4. KEGG and Reactome pathway enrichment analyses. a and b.

498 Kyoto Encyclopedia of Genes and Genomes (KEGG) (a) and Reactome (b) pathway enrichment

499 analysis of COVID-19 versus control brain DEGs. Gene ranks were determined by signed -log10

500 false discovery rates of DEGs. FDR, gene set enrichment analysis false discovery rate.

501

502 
medRxiv preprint doi: https://doi.org/10.1101/2021.11.24.21266779; this version posted November 24, 2021. The copyright holder for this preprint (which was not certified by peer review) is the author/funder, who has granted medRxiv a license to display the preprint in perpetuity.

It is made available under a CC-BY-NC-ND 4.0 International license .

a
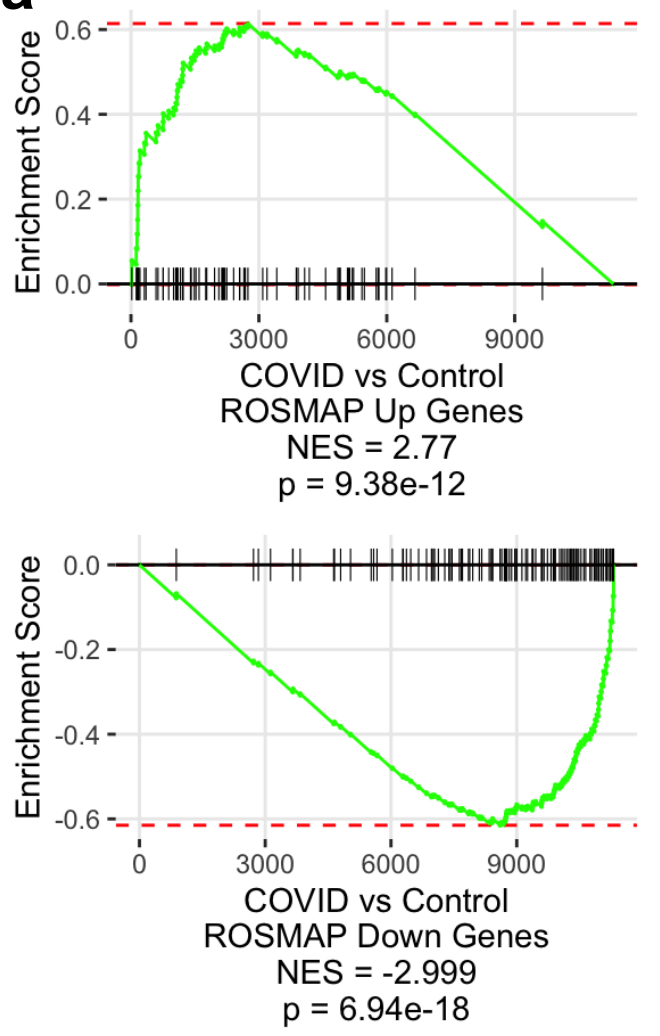

b
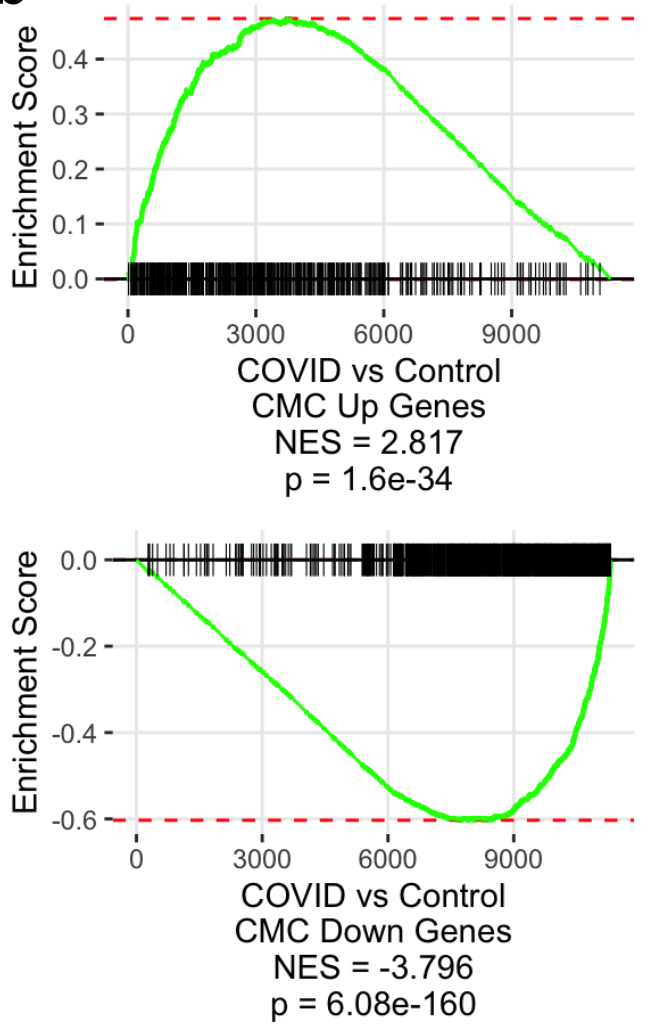

C
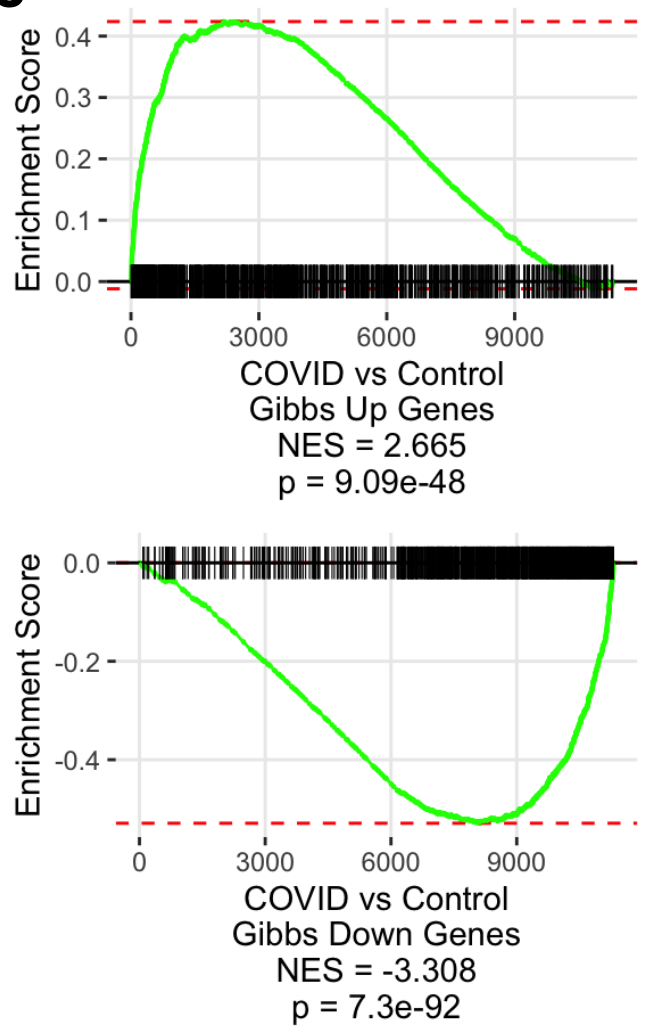
medRxiv preprint doi: https://doi.org/10.1101/2021.11.24.21266779; this version posted November 24, 2021. The copyright holder for this preprint (which was not certified by peer review) is the author/funder, who has granted medRxiv a license to display the preprint in perpetuity. It is made available under a CC-BY-NC-ND 4.0 International license.

503 Supplementary Figure 5. COVID-19 induces molecular signatures found at late age in the

504 human brain. a-c. Gene set enrichment analysis of COVID-19 DEGs, using significantly up- (top)

505 or down-regulated genes (bottom) in the ROSMAP (a), Common Mind Consortium/CMC (b), and

506 Gibbs (c) cohorts as gene sets. DEG ranks were assigned by signed -log10 false discovery rates

507 from COVID-19 versus control subject frontal cortex. NES, normalized enrichment score. p, GSEA

508 p-value.

509

510 
medRxiv preprint doi: https://doi.org/10.1101/2021.11.24.21266779; this version posted November 24, 2021. The copyright holder for this preprint (which was not certified by peer review) is the author/funder, who has granted medRxiv a license to display the preprint in perpetuity.

It is made available under a CC-BY-NC-ND 4.0 International license .
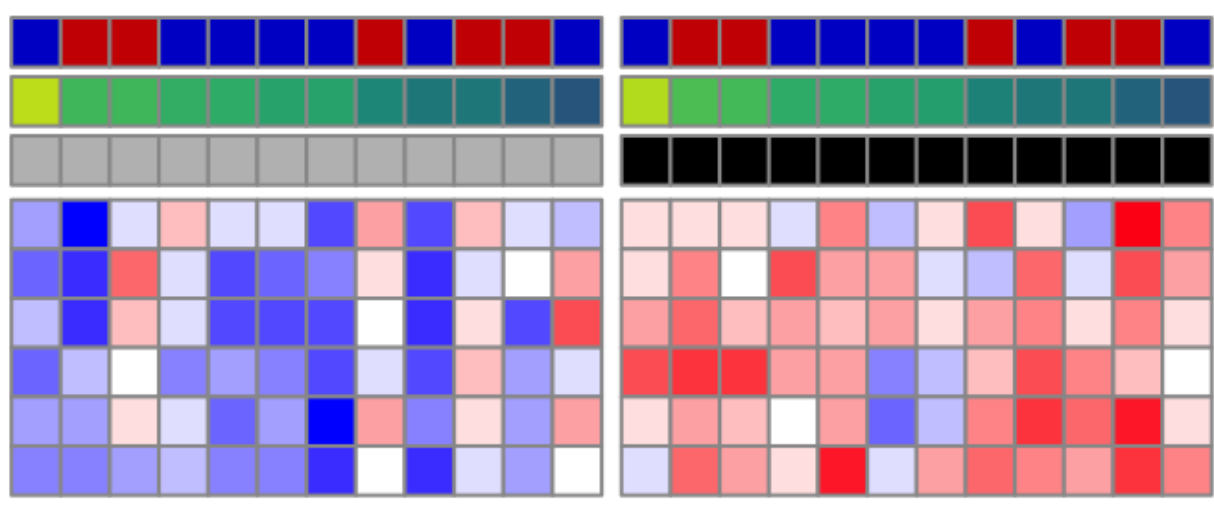

Sex

Age

Group

VWF

VSIG4

CD163

TXNIP

CP

MPZL2

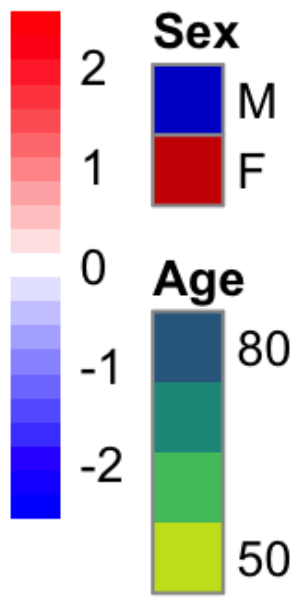

Group

Control

COVID

\section{Supplementary Figure 6}


medRxiv preprint doi: https://doi.org/10.1101/2021.11.24.21266779; this version posted November 24, 2021. The copyright holder for this preprint (which was not certified by peer review) is the author/funder, who has granted medRxiv a license to display the preprint in perpetuity. It is made available under a CC-BY-NC-ND 4.0 International license .

511 Supplementary Figure 6. Gene expression patterns of a published brain aging gene

512 signature. Heatmap of relative gene expression levels of a brain aging-distinguishing gene

513 signature from [29] across COVID-19 and control samples. Color legend, scaled gene expression

514 levels across subjects, normalized via variance-stabilized transformation.

515

516 
medRxiv preprint doi: https://doi.org/10.1101/2021.11.24.21266779; this version posted November 24, 2021. The copyright holder for this preprint (which was not certified by peer review) is the author/funder, who has granted medRxiv a license to display the preprint in perpetuity.

It is made available under a CC-BY-NC-ND 4.0 International license .

a
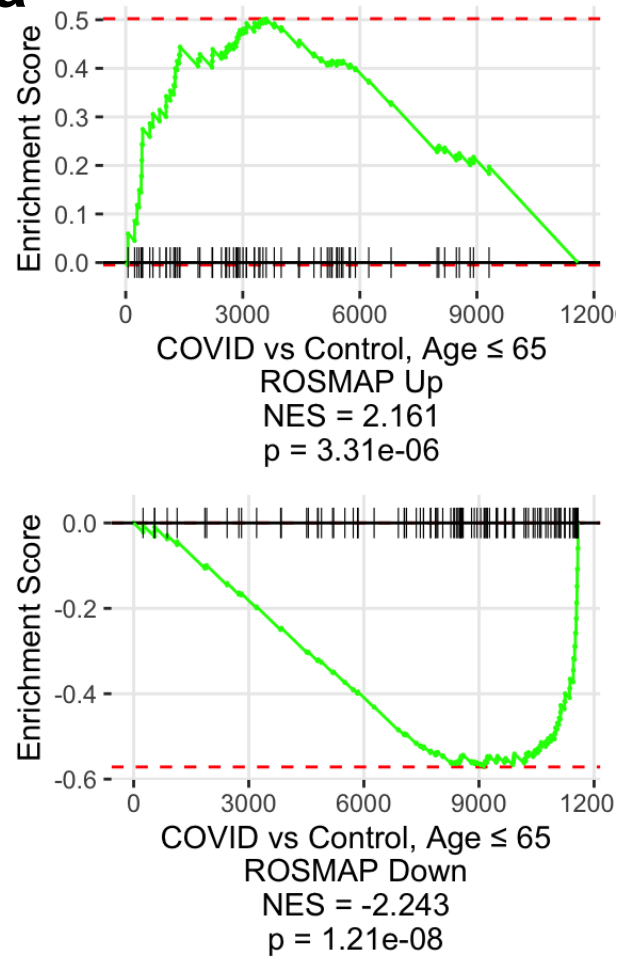

b
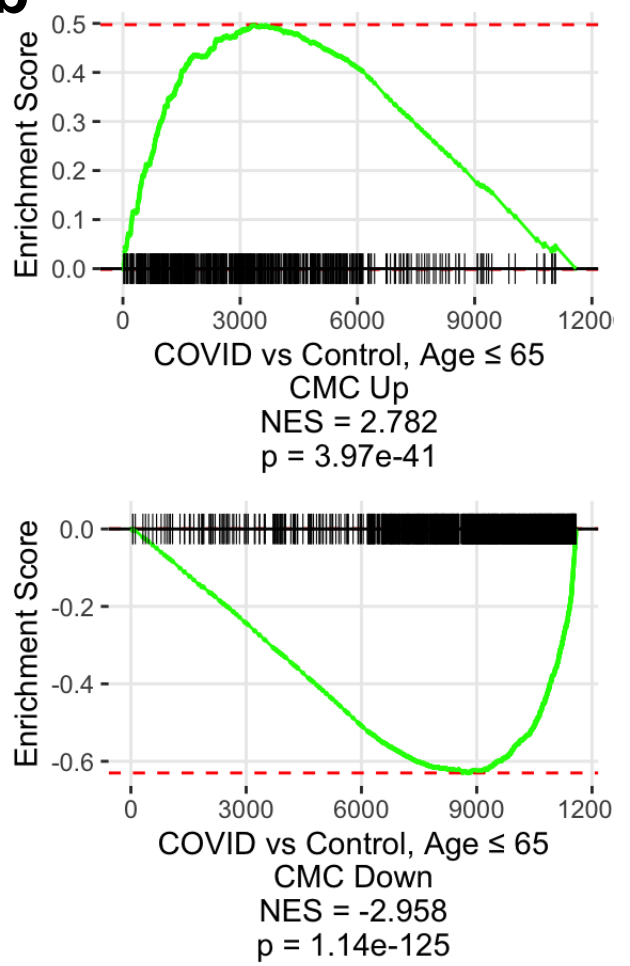

C
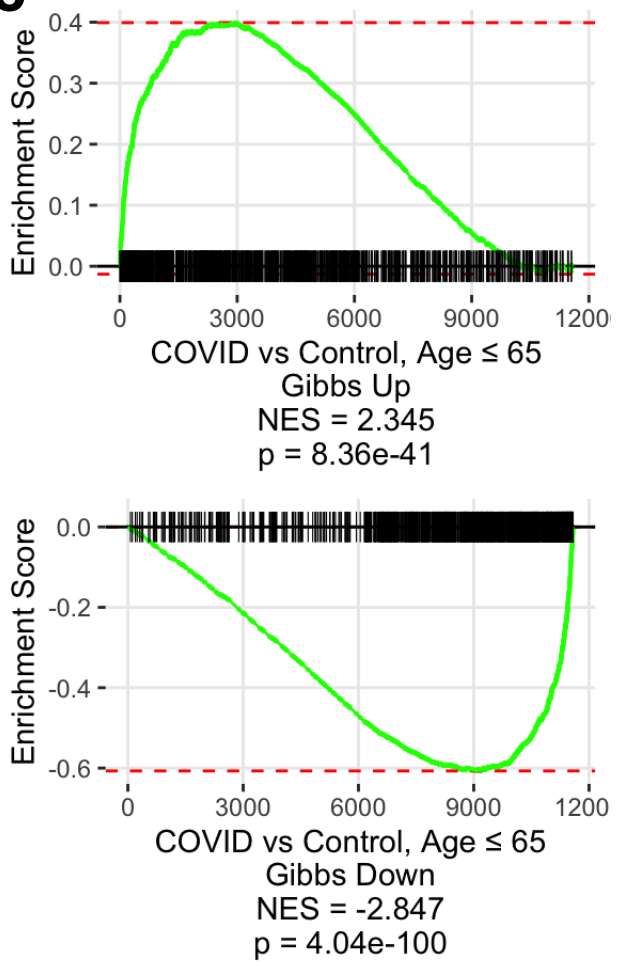
medRxiv preprint doi: https://doi.org/10.1101/2021.11.24.21266779; this version posted November 24, 2021. The copyright holder for this preprint (which was not certified by peer review) is the author/funder, who has granted medRxiv a license to display the preprint in perpetuity. It is made available under a CC-BY-NC-ND 4.0 International license .

517 Supplementary Figure 7. COVID-19 induces molecular signatures found at late age in

518 individuals $\leq \mathbf{6 5}$ years of age. a-c. Gene set enrichment analysis of COVID-19 DEGs among

519 individuals $\leq 65$ years of age, using significantly up- (top) or down-regulated genes (bottom) in

520 the ROSMAP (a), Common Mind Consortium/CMC (b), and Gibbs (c) cohorts as gene sets. DEG

521 ranks were assigned by signed -log10 false discovery rates from COVID-19 versus control subject

522 frontal cortex among individuals $\leq 65$ years of age. NES, normalized enrichment score. p, GSEA

523 p-value.

524

525 
medRxiv preprint doi: https://doi.org/10.1101/2021.11.24.21266779; this version posted November 24, 2021. The copyright holder for this preprint (which was not certified by peer review) is the author/funder, who has granted medRxiv a license to display the preprint in perpetuity.

It is made available under a CC-BY-NC-ND 4.0 International license .

a

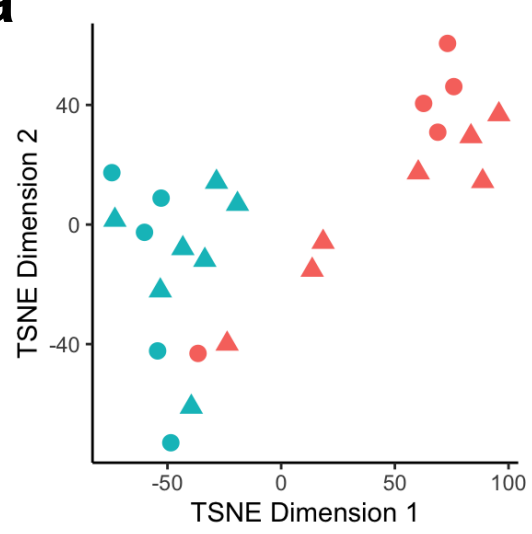

b

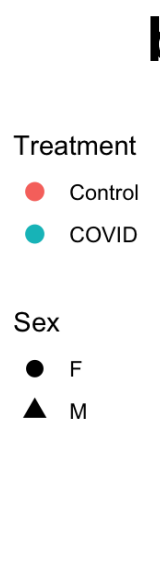

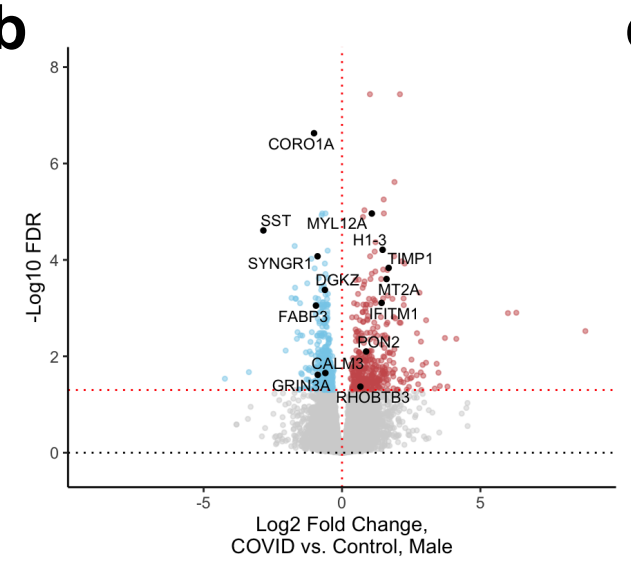

e
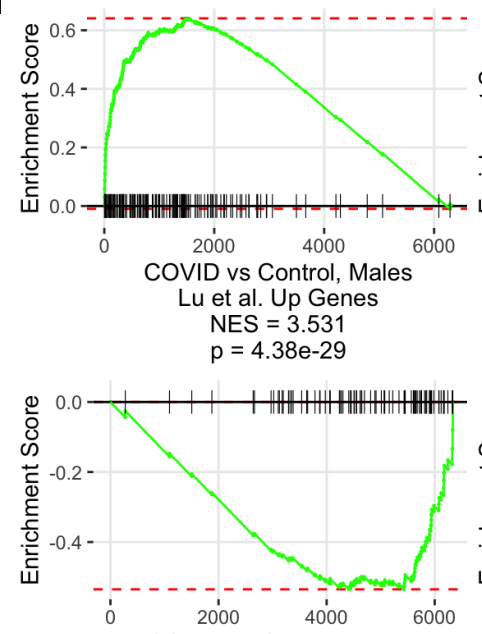

COVID vs Control, Males

Lu et al. Down Genes

NES $=-2.678$

$p=1.22 \mathrm{e}-10$
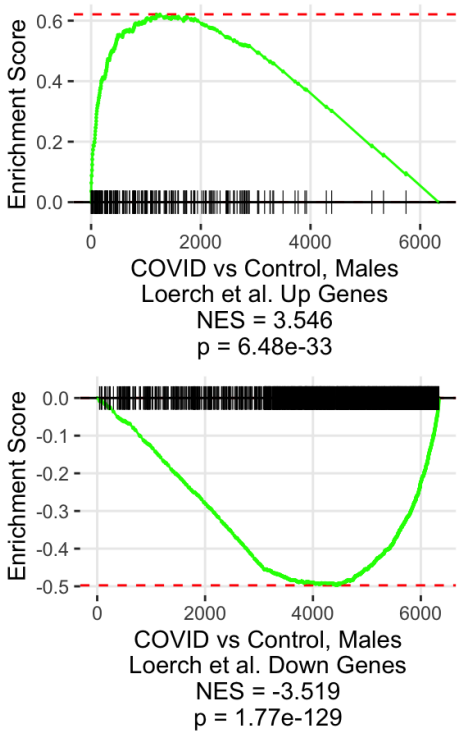

C

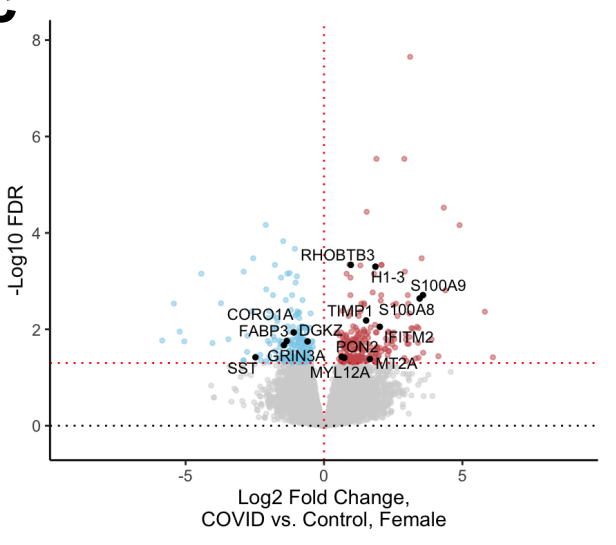

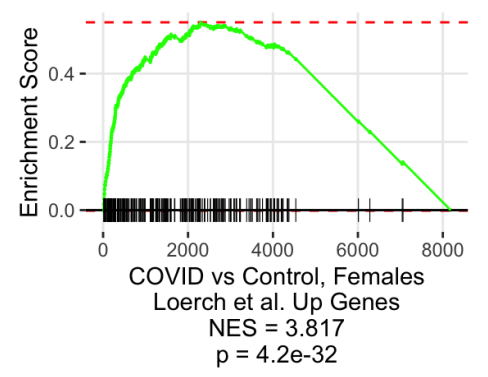
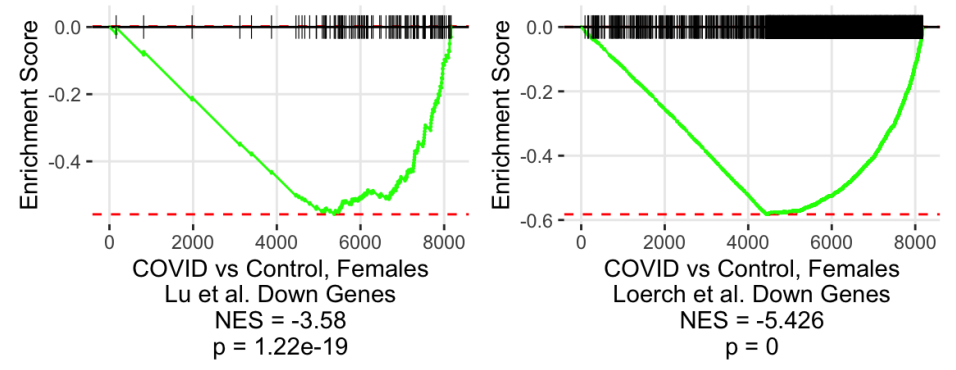
medRxiv preprint doi: https://doi.org/10.1101/2021.11.24.21266779; this version posted November 24, 2021. The copyright holder for this preprint (which was not certified by peer review) is the author/funder, who has granted medRxiv a license to display the preprint in perpetuity.

It is made available under a CC-BY-NC-ND 4.0 International license .

526 Supplementary Figure 8. Aging effects of COVID-19 in male and female human brains. a.

527 TSNE analysis of frontal cortex transcriptomes from COVID-19 cases and uninfected controls,

528 including sex annotations. b and c. Volcano plots representing the DEGs of the frontal cortex of

529 COVID-19 cases versus controls among males (b, $n=7 /$ group) or females (c, $n=5 / g r o u p)$. Red

530 points, significantly upregulated genes among COVID-19 cases (false discovery rate $<0.05$ ). Blue

531 points, significantly downregulated genes among COVID-19 cases. Black points, significant

532 genes with corresponding gene symbols. d and e. Gene set enrichment analysis of COVID-19

533 DEGs among males (d) and females (e), using significantly up- (top) or down-regulated genes

534 (bottom) in the Lu et al. (2004) (left) and Loerch et al. (2008) (right) cohorts as gene sets. DEG

535 ranks were assigned by signed -log10 FDR values from COVID-19 versus control brains among

536 males and females. NES, normalized enrichment score. p, GSEA p-value. 